\title{
THE ROLE OF REGIONAL STATE INTEGRATION ORGANIZATIONS IN COMBATING PIRACY BETWEEN AFRICA AND ASIA
}

\author{
Cezary $\mathrm{Mik}^{\star}$
}

\section{Preliminary Remarks}

Maritime piracy has been a recognized phenomenon for ages. Although the intensity and scope thereof have been subject to fluctuations, the law of nations has always considered piracy negatively; as an act directed against humankind (with pirates deemed as hostes humani generis). Nowadays, intensive developments in international seaborne trade, the fishing industry and marine tourism have resulted in providing an almost natural feed for piracy. This trend was further facilitated by such factors as the internal financial and technical inability of many states to conduct necessary marine or airborne operations on a larger scale, as well as the existence of internal conflicts in some of the coastal states which, in some instances, have even led to the dissolution of state power (so called failed states).

Historically, the combating of maritime piracy fell exclusively within the realms of state-action. Today, it has acquired a more organized shape:

* Cardinal Stefan Wyszynski in Warsaw. Professor, Head of International and European Law Department, Law and Administration Faculty. 
it is subject to both individual and collective action; it has become a challenge for many global and regional international organizations with competences of a general or specialized nature. Towards the end of the $20^{\text {th }}$ century and at the beginning of the $21^{\text {st }}$ century, regional state integration organizations (RSIOs) have also joined the fray.

Although the first timid (and usually unstable) attempts at state integration can be traced back in history (e.g. to the $19^{\text {th }}$ century), it is only the second half of the $20^{\text {th }}$ century that witnessed development of integration processes on a global scale. Consequently, regional and sub-regional organizations seeking the integration of states and their peoples emerged on all continents. In relation to traditional international organizations, the former display two differentiae specificae. On the one hand, their aim and subject of activity is directed not so much at state cooperation but, rather, at integration of at least social and economic systems as well as legal systems (hence these are first and foremost regional state integration organizations) at all levels (beginning at the governmental level, through regional, local and even individual one). The scope of integration, however, broadens (though its scope, standard and especially the practical prospects to integrate differ in each and every continent). On the other hand, at least in the European model of integration (nowadays the majority of RSIOs develop in line with that model), the very existence of the organization is linked with the fact that it acquires an autonomous legal personality, expands its institutional structures, and with the fact that an autonomous legal order emerges and builds up and the gradual taking-over, or at least the restriction, of state competences, not only in mutual relations but also pro foro externo.

Today, maritime piracy constitutes a global phenomenon; however, in some regions of the world it manifests itself with particular intensity. These are, in particular, the north-west parts of the Indian Ocean, together with its appertaining seas and bays (between the coasts of Africa and Asia; the western part of the Indian Ocean), the Malacca Strait and South-China Sea, the Gulf of Guinea, together with South America and the Caribbean. It is worth underlining that the first two of the aforementioned regions, given the intensity of piratical attacks and their economic importance, are of primary importance. They are, accordingly, at the centre of attention of states and international organizations. 
The aim of this paper is to undertake a review, summary and assessment of actions undertaken by the RSIO in relation to maritime piracy between the coasts of Africa and Asia. This analysis will focus primarily on the activity of the European Union (EU) and African Union (AU; it is assumed here that the latter constitutes an integration organization $^{1}$ ), together with that of selected sub-regional integration organizations, ${ }^{2}$ including in particular the Intergovernmental Authority on Development (IGAD) ${ }^{3}$ and, to a lesser extent, the Common Market of Eastern and Southern Africa (COMESA) ${ }^{4}$ and the East African Community $(E A C)^{5}$. The geographical scope of these organizations' activity is fairly well defined. It includes the Horn of Africa (understood as embracing Djibouti, Ethiopia, Eritrea, Somalia), as well as the Gulf of Aden, the Red Sea and the Western Indian Ocean. It is the result not only from the 'geographical continuity' of the region or the interconnected nature

1 The Constitutive Act of the African Union states that one of the purposes of the African Union is, inter alia, "to accelerate the political and socio-economic integration of the continent", "promote sustainable development at the economic, social and cultural levels as well as the integration of African economies" and "coordinate and harmonize the policies between the existing and future Regional Economic Communities for the gradual attainment of the objectives of the Union" (Article 3). The organizational structure of the Union and some institutional arrangements are modelled on the European Union. Moreover, the Constitutive Act supersedes and substitutes the Abuja Treaty constituting African Economic Community (Article 33 para. 2), that is legally linked to the African Union. See also R.F. Oppong, Legal Aspects of Economic Integration in Africa, Cambridge 2011, at p. 64 et seq. and at p. 165 et seq.; B. Gueye, Réflexion sur une experience d'intégration: l'Union africaine [in:] Regards croisés sur les integrations regionales: Europe, Amériques, Afrique, C. Flaesch-Mougin, J. Lebullenger, Bruxelles 2010, at p. 185 et seq.

2 See more on this subject: J.T. Gathii, African Regional Trade Agreements as Legal regimes, Cambridge 2011.

3 See the organization's webpage: http://www.igad.org/. IGAD member states (Djibouti, Eritrea, Ethiopia, Kenya, Somalia, South Sudan, Sudan, Uganda) are interested to a significant extent in Somalia and Somali piracy. See also J.T. Gathii, op. cit., at p. 156 et seq.

4 Official site of the COMESA: http://www.comesa.int/. Member States of the organization are: Burundi, Comoros, DRC, Dijbouti, Egypt, Eritrea, Ethiopia, Kenya, Libya, Madagascar, Malawi, Mauritius, Rwanda, Seychelles, Sudan, Sewaziland, Uganda, Zambia, Zimbabwe. See also J.T. Gathii, op. cit., at p. 165 et seq. and at p. 265 et seq.

5 Official site of the EAC: http://www.eac.int/. Member States of the EAC are Burundi, Kenya, Rwanda, Tanzania, Uganda. See also: J.T. Gathii, op. cit., at p. 181 et seq. and at p. 268 et seq. 
of maritime trade routes, but also from the geographical coverage of the piratical activities stemming mostly from Somalia (hence this paper will also employ the term 'Somali piracy'). The existence of the region thus defined is further confirmed in the documents of various organizations, including the United Nations, the International Maritime Organization (IMO), the International Maritime Bureau and others.

To attain the aim set in this paper it is necessary to embark on a legal analysis of the character, purposes, extent, methods and efficacy of activities undertaken by regional integration organizations in relation to Somali piracy. Given the more extensive access to documents, this aim may be pursued to a fuller extent in the case of the European Union and to a lesser extent in the case of African integration organizations. In order to properly understand the activities of RSIOs it is necessary to briefly present the causes, ramifications, scope, intensity and specificity of Somali piracy. Moreover, it shall be underlined that the activity of RSIOs between the coasts of Africa and Asia is not autonomous in character. It is influenced by the normative and operational activity of other international actors - both states and international organizations, chiefly the United Nations and the IMO. Consequently, the presentation and assessment of integration organizations must be preceded by remarks concerning the general understanding of piracy from the standpoint of international law and, specifically, of the United Nations' and IMO's activities in relation to the analysed region and to the role of RSIOs.

\section{The Causes and Factors that Determine Maritime Piracy between the Coasts of Africa and Asia}

The roots of piracy between the coasts of Africa and Asia, including its significant development at the turn of the $20^{\text {th }}$ and $21^{\text {st }}$ centuries, undoubtedly lie in the fall of the Somali state. ${ }^{6}$ This sizable country

6 See the data on Somalia at the CIA website: https://www.cia.gov/library/ publications/the-world-factbook/geos/so.html (accessed: 31.10.2012), as well as information concerning the period 2009-2012 at the Index of Failed States, http://www. foreignpolicy.com/failed_states_index_2012_interactive. See also the report of L. Ploch, Ch.M. Blanchard, R. O’Rourke, R. Chuck Mason, R.O. King, Piracy off the Horn of Africa, 
(comprising over 637,000 $\mathrm{km}^{2}$ ), which gained independence in 1960, fell victim - following the long period of gruesome, authoritarian rule of Mohamed Siad Barre (1969-1991) - to a tribal civil war (beginning in 1988) that ultimately led to anarchy. By 1991, tribes that occupied northeast Somalia declared the creation of the Somaliland state (comprising approximately $138.000 \mathrm{~km}^{2}$; albeit that it still remains unrecognized by the international community) which continues to exist and has acquired a certain stability and is currently developing into a constitutional democracy. In 1988, some tribes declared the creation of semi-autonomous state known as Puntland (central Somalia; comprising over 212,000 km²). It entered into a territorial dispute with Somaliland and, moreover, was wrought with internal conflicts. No new state was established in the remainder of the territory. Civil war aggravated and multiplied the problems connected with food security. Hunger emerged, which surely prompted inhabitants to plundering, illegal fishing ${ }^{7}$ and piracy and, on the other hand, revealed the need for humanitarian assistance.

Following an unsuccessful, two-year humanitarian mission of the United Nations (1993-1995) the problems even exacerbated. Humanitarian assistance began (the UN World Food Programme and African Union) and, in the year 2000, a peace conference at Djibouti took place. It led to the creation, and international recognition, of a Transnational Federal Government which, however, failed to provide

Congressional Research Service Report for Congress, 19.4.2010, 7-5700, www.crs.gov, R40528, at pp. 6-18, that broadly discusses the causes and factors that determine Somali piracy and analyses the character and methods of piratical activities; Piracy off the Somali Coast. Workshop commissioned by the Special Representative of the Secretary General of the UN to Somalia Ambassador Ahmedou Ould-Abdallah, Nairobi 20-21 November 2008, Final report. Assessment and recommendations, Nairobi, 21.11.2008, http://www. asil.org/files/somaliapiracyintlexpertsreportconsolidated1.pdf.

7 In the Somali Exclusive Economic Zone, overfishing is endemic in character. It is reported that as many as hundreds of vessels may be engaged in this activity. See: D. Guilfoyle, Piracy off Somalia: UN Security Council Resolution 1816 and IMO Regional Counter-Piracy Efforts, "International and Comparative Law Quarterly" 2008, Vol. 57, No. 2, at p. 692. On the relations of piracy and illegal fishing in the context of the reactions of states and international organizations thereto see also: J. Hughes, The Piracy-Illegal Fishing Nexus in the Western Indian Ocean, Independent Strategic Analysis of Australian's Global Interests, Strategic Analysis Paper, 10.2.2011, http://somfin.org/ files/0/9/6/4/8/293199-284690/Piracy_IUU_relation.pdf. 
for stability and security, in particular due to the fact that it waged war with Al-Shabaab (an organization that is reportedly linked with Al-Qaida). Moreover, in 2007 the war with Ethiopia over Ogaden took place. It was only the new agreement of 2009 that enabled the first presidential and parliamentary elections to take place which, in turn, acted as the catalyst for the stabilization process, the first period of which lasted from 2009 until September 2012.

Significant political instability, civil war and hunger gave rise to a major wave of refugees (ca. 50.000) and also contributed to the fact that plundering and piracy were more commonly undertaken. Maritime piracy had as its harbor the territory of Puntland (Eyl and Garad districts) and the Mudug area (Harardera district). It enabled the operation of pirates from certain Somali ports (including the capital of Somalia - Mogadishu). Piracy was also facilitated by the long and diverse coastline, amounting to 3,000 kilometres in length.

Additionally, the very geographical location of Somalia, in a pivotal shipping area, i.e. near the Gulf of Aden where important trade routes from East Africa and Asia are located, through the Red Sea, to Europe (it is estimated that annually approximately 33,000 ships sail through the Gulf) facilitated the development of piracy. Ships on these routes have become attractive prey for pirates. Maritime trade and fishing were greatly disrupted by piracy. This, in turn, has had financial implications. The Organization known as Oceans Beyond Piracy assesses that, in 2011 alone, the costs of Somali piracy in the analysed region amounted to somewhere between 6.6-6.9 billion USD. This includes in particular the costs of military operations but also increased costs related to speedier travel, security equipment, guards and insurance. ${ }^{8}$ However, one must also bear in mind that the costs resulting from the fact that maritime routes required modification and the losses borne by some of the states in the region that are dependent on fishing that used to take place in the area covered by the piratical attacks or on transport via specific sea routes (e.g. lower incomes of the Egyptian budget given more infrequent

8 The Economic Cost of Somali Piracy 2011, Working Paper, One Earth Future Foundation, at p. 39, http://oceansbeyondpiracy.org/sites/default/files/economic_cost_ of_piracy_2011.pdf, see also L. Ploch, Ch.M. Blanchard, R. O’Rourke, R. Chuck Mason, R.O. King, op. cit., pp. 6-18. 
usage of the Suez Canal, or the Seychelles budget which depends heavily on tuna fishing). ${ }^{9}$

\section{Statistical and Analytical Data on Maritime Piracy between Africa and Āsia}

The United Nations Office on Drugs and Crime analytical report highlights that maritime piracy in the Somali region, the Red Sea and the Gulf of Aden occurred firstly, as a bigger problem, in 1995. In time, it has had the tendency to expand geographically, extending to cover the Arab Sea and the western part of the Indian Ocean. The number of piratical attacks in the region increased significantly in 2006, reaching its peak between 2008 and 2011. ${ }^{10}$ In 2009, this number was for the first time higher than in other parts of the world.

According to the International Maritime Organization's reports on acts of piracy and armed robbery against ships for 2011, the number of piracy attacks globally amounted to 544 (an increase of 55 in comparison with 2010). As many as 223 incidents were reported in the area off East Africa (after a certain downfall in 2010 - 172 incidents - this signified a return to the high numbers of 2009: 222 incidents; for comparison: the number of piracy attacks in the South China Sea and the Malacca Strait was 137 in 2010 and 135 in 2011). It is worth noting that the number of attacks in the Indian Ocean reduced from 77 incidents in 2010 to 63 in 2011, whereas it increased in the Arab Sea from 16 in 2010 to 28 in 2011. The IMO reported also mentions the lower efficiency of pirate attacks stemming from Somalia. Whereas in 2010172 ships were attacked, of which 50 were hijacked, in 2011286 ships were attacked, of which 33 were hijacked. ${ }^{11}$ According to the International Maritime

9 See: UNCTAD, Review of Maritime Transport 2011, chapter 1, New York - Geneva 2011, at p. 29, http://unctad.org/en/Docs/rmt2011ch1_en.pdf.

10 United Nations Office on Drugs and Crime, Maritime Piracy, at pp. 194, 197; http://www.unodc.org/documents/data-and-analysis/tocta/9.Maritime_piracy.pdf. This report provides data until 2009.

11 International Maritime Organization, Reports on Acts of Piracy and Armed Robbery Against Ships. Annual Report 2011, at pp. 1-3; available at: http://www. imo.org/OurWork/Security/SecDocs/Documents/PiracyReports/180_Annual2011.pdf 
Bureau, in the first 11 months of 2012 (until $3^{\text {rd }}$ December) the number of pirate attacks amounted to 278 incidents globally, and in the case of Somalia region alone: $71 .{ }^{12}$ It is hence the first year when one can observe a downward trend.

As reported by the NATO Shipping Centre, pirate activity around the world (and this surely applies to the Somalia region as well), given the climate factors (in particular monsoon periods) finds its peak between the months of February - May and October - November. Against this background, 2011 was somewhat exceptional, since a significant number of attacks were conducted in January (approx. 30). ${ }^{13}$

One can highlight, taking only into account the period of 2009-2012 that, between Africa and Asia, ships flying various flags were attacked, however lots of these incidents involved so called flags of convenience (especially from Panama or Liberia). From the perspective of the characteristics of the ship attacked, it shall be noted that in 2011 these were mostly trade ships, including mostly freighters (general cargo $-11 \%$, tankers $-15 \%$, bulk carriers $-26 \%$, chemical tankers $-15 \%)$ and fishing vessels (18\%). ${ }^{14}$

Whereas, on a global analysis, a significant majority of pirate attacks (80\% in 2008) took place within 12 nautical miles (nm) from the coast, in the case of Somalia attacks in international waters are predominant. They are frequently undertaken from mother-ships (as far as $1.000 \mathrm{~nm}$ from the Somali coastline). ${ }^{15}$ At a global level, ships are usually attacked

(31.10.2012). IMO has collected statistics on pirate attacks since 1984. Since then as many as 6260 incidents were reported globally.

12 International Maritime Bureau, http://www.icc-ccs.org/piracy-reporting-centre/ piracynewsafigures; http://www.icc-ccs.org/piracy-reporting-centre/prone-areas-andwarnings (Updated: 24.9.2012).

13 NATO Shipping Centre, http://www.shipping.nato.int/Pages/Piracystatistics.aspx (Updated: 2.9.2012).

14 Oceans Beyond Piracy (The Economic Cost of Somali Piracy 2011, Working Paper, One Earth Future Foundation, at p. 9), http://oceansbeyondpiracy.org/sites/default/files/ economic_cost_of_piracy_2011.pdf. See also on various threats related to Somali piracy: A. Odeke, Somali Piracy - Effects on Oceanborne Commerce and Regional Security and Challenges to International Law and World Order, 'Australian and New Zealand Maritime Law Journal' 2011, Vol. 25, No. 1, at pp. 139-146.

15 Formally, Somalia's territorial sea has $12 \mathrm{~nm}$ in breadth. However in 1972 Somalia claimed 200 nm territorial sea. See M.D. Fink, R.J. Galvin, Combating Pirates off the Coast 
while stationary. However, in the case of Somali piracy, most attacks are directed against ships en route. ${ }^{16}$

Pirate attacks happen rapidly and usually last no longer than 15-30 minutes. This is facilitated by the fact that pirates use speedy, small boats. Moreover, they are equipped with GPS transmitters. There is usually a specified group of individuals involved (more than 5), more often than not minors, capable of handling sharp-edged weapons and firearms (including automatic weapons and rocket propelled grenades), thereby creating the impression that they are militarily trained or ex-sailors. Also, former fishermen are involved. ${ }^{17}$ Pirates usually attack ships, hijack them and hide them in internal waters (harbours, river estuaries), demanding a ransom for their return. Thanks to them, piracy became a way for whole tribes to become rich. Ransom also contributes financially to criminal organizations. ${ }^{18}$ Ships can be held hostage for as long as one year. According to the International Maritime Bureau, as of 3.12.2012, Somali pirates held 9 ships and 147 hostages. ${ }^{19}$ Unfortunately, it has transpired on several occasions that, during or as a result of attacks, or during attempts to free hijacked ships, not only the pirates but also crew members were killed. This number rose from 8 to 24 casualties in the period of 2009-2011. ${ }^{20}$ It also happens that pirates slaughter the whole

of Somalia: Current Legal Challenges, 'Netherlands International Law Review' 2009, Vol. LVI, at p. 370.

16 W.M. Reisman, B.T. Tennis, Combating Piracy in East Africa, "The Yale Journal of International Law Online' 2009, Vol. 35, at p. 16.

17 See International Maritime Bureau, Piracy and Armed Robbery Prone Areas and Warnings, http://www.icc-ccs.org/piracy-reporting-centre/prone-areas-and-warnings and International Maritime Organization, Reports on Acts of Piracy and Armed Robbery Against Ships. Annual Report 2011, Annex 2 and 3; http://www.imo.org/OurWork/ Security/SecDocs/Documents/PiracyReports/180_Annual2011.pdf (31.10.2012).

18 A. Lelarge, La Somalie entre anarchie et piraterie, 'Journal du droit international' 2010, No. 137, at p. 451, notes that pirates often had at its disposal bigger military power and financial resources than state forces.

19 International Maritime Bureau, http://www.icc-ccs.org/piracy-reporting-centre/ piracynewsafigures; http://www.icc-ccs.org/piracy-reporting-centre/prone-areas-andwarnings (Updated: 24.9.2012).

20 Data according to: Oceans Beyond Piracy (The Economic Cost of Somali Piracy 2011, Working Paper, One Earth Future Foundation, at p. 36); http://oceansbeyondpiracy. org/sites/default/files/economic_cost_of_piracy_2011.pdf. 
crew in order to take possession of a 'ghost-ship' which is subsequently used to other criminal ends. ${ }^{21}$

\section{The Definition of Piracy in the Modern International Law}

Throughout the ages, there was no uniform definition of piracy. The first modern definition was coined in the Geneva Convention on the High Seas, concluded on 29.4.1958 (Article 15). ${ }^{22}$ Nowadays, the legal regime on piracy is laid down by the UN Convention on the Law of the Sea, concluded on 10.12.1982 (UNCLOS). ${ }^{23}$ Both the definition and the principles concerning the of piracy that are enshrined in UNCLOS (Articles 100-107 and 110) repeat the former Geneva Convention regulations. ${ }^{24}$ They can be considered as reflecting customary international law. ${ }^{25}$

Article 101 UNCLOS states that:

Piracy consists of any of the following acts:

(a) any illegal acts of violence or detention, or any act of depredation, committed for private ends by the crew or the passengers of a private ship or a private aircraft, and directed:

(i) on the high seas, against another ship or aircraft, or against persons or property on board such ship or aircraft;

(ii) against a ship, aircraft, persons or property in a place outside the jurisdiction of any State;

(b) any act of voluntary participation in the operation of a ship or of an aircraft with knowledge of facts making it a pirate ship or aircraft;

21 W.M. Reisman, B.T. Tennis, op. cit., at p. 17.

22 The Convention entered into force on 30.9.1962. As of 1.1.2013 there are 63 state parties to the Convention. UNTS, Vol. 450, at p. 11.

${ }^{23}$ It entered into force on 16.11.1994. As of 1.1.2013 there are 164 parties to the Convention, including the European Union. UNTS, Vol. 1833, p. 3.

24 See also the reflections on the definition of piracy, its character and relations with terrorism by: J.-F. Leclercq, La lute contre la piraterie modern entravant la circulation maritime et le droit fundamental des Nations unies, "Revue de droit international et de droit comparé" 2011, No. 1, pp. 20-43; O. Elagab, Somali Piracy and International Law: Some Aspects, „Australian and New Zealand Maritime Law Journal” 2010, Vol. 24, No. 2, pp. 61-64.

25 See also: D.R. Rothwell, T. Stephens, The International Law of the Sea, Oxford-Portland 2010, at pp. 162-164. 
(c) any act of inciting or of intentionally facilitating an act described in subparagraph (a) or (b).

Hence, the Convention on the Law of the Sea defines piracy as an illegal act (a crime), committed for private ends (however, it need not be understood as an act committed with solely financial motives, animus furandi; it rather refers to an act that is non-public in nature ${ }^{26}$ ), involving violence, detention, or depredation, that is committed on the high seas or in a place outside the jurisdiction of any state, by the crew or passengers of a private ship or aircraft, directed against another ship or aircraft (public or private; freight, tourist or other), persons or property onboard (so called two-vessel rule and private ship-rule; an act may be also committed by a mutinied crew of the warship or government ship; Article 102 UNCLOS). ${ }^{27}$ Any ship becomes a pirate ship when it is intended by the persons in dominant control to be used for the purpose of committing one of the acts referred to in Article 101 or when it has been used to commit any such act and it remains under the control of the persons guilty thereof (Article 103 UNCLOS).

All states are obliged to cooperate to the fullest possible extent in the repression of piracy (Article 100). A ship may be boarded in instances where there are reasonable grounds to believe that it is engaged in piracy; this situation provides therefore for the right of visit (Article 110 (1) (a)).

26 D. Guilfoyle, op. cit., at p. 693; M.D. Fink, R.J. Galvin, op. cit., at p. 375, point out in this context that the international law of piracy does not regulate act of prima facie piratical character that were committed for political ends or were terrorist in nature („From the political point of view with regards to combating piracy there is thus no need to look for linkages between pirates and terrorists. Moreover, there is no conclusive evidence of a broader terrorist network or strategy"). In practice, however, it may be hard to establish the true nature of a given act, at least while an action towards an allegedly pirate ship is undertaken. Moreover, at least in the case of Somalia, the existence of a link between pirates and Al-Shabaab organization, reportedly linked to terrorists, may not be excluded. In any case, the fact that a given act combines elements of the crime of piracy and terrorist or political one should not automatically derogate the application of the international law of piracy. A. Lelarge voices similar doubts as to the qualification of certain categories of acts as piracy; A. Lelarge, op. cit., at pp. 460-461.

27 For a broader definition of the crime of piracy see: I. Shearer, Piracy, Max Planck Encyclopedia of Public International Law, www.mpepil.com (accessed on 1.7.2011); M.D. Fink, R.J. Galvin, op. cit., at pp. 369-375. 
In accordance with the provisions of UNCLOS, the principle of universal jurisdiction applies to pirate ships. Hence, every state may seize a pirate ship, arrest the persons and seize the property onboard. The courts of the state having carried out the seizure are entitled, subject to the rights of third parties acting in good faith, to decide on the penalties to be imposed and to determine the action to be taken with regard to the ship or property (Article 105). ${ }^{28}$ It needs to be underlined in this context that such seizure may be carried out only by warships or other government ships (Article 107). The Convention further states that any seizure carried out without adequate grounds shall render the state liable to the state whose nationality is possessed by the seized ship (Article 106). ${ }^{29}$

The treaty definition of piracy (both in the Geneva Convention and in UNCLOS) places emphasis on the place where an act was committed. This act must occur beyond the scope of jurisdiction of any state, i.e. in a place where territorial sovereignty does not apply. It is of lesser importance what sort of ship fell victim to piratical attack and from what kind of a ship the attack was launched. The Convention states that the provisions concerning piracy apply in the Exclusive Economic Zone, provided they are compatible with the provisions of Part V of UNCLOS (Article 58 (2) UNCLOS). This zone also includes, subject to specific rights of coastal states, any Contiguous Zone (if such was established; Article 33) to the extent that extends beyond the territorial sea (see Article 55). Consequently, the Convention does not perceive acts committed in the territorial sea (and archipelagic waters) as piracy. States retain in these zones practically exclusive jurisdiction over ships (Articles 2-32 and 49-54 UNCLOS). ${ }^{30}$

28 On the universal jurisdiction (understood as compétence de police and compétence de juridiction) and its restrictions: A. Lelarge, op. cit., at pp. 461-467. See also comparative analysis with regard to practice of states in implementing universal jurisdiction towards pirates in various regions: E. Kontorovich, S. Art., An Empirical Examination of Universal Jurisdiction for Piracy, 'American Journal of International Law' 2010, Vol. 104, No. 3, at pp. 436 et seq.

29 See also on the form and legality of the naval operations, exercising various rights towards ships on the high seas, as well as on flag state, port state and third state jurisdiction and the seizure of ships and on the universal jurisdiction: A. Odeke, op. cit., at pp. 146-157.

30 For a very interesting analysis of the states' scope of jurisdiction over pirates and problems related to its implementation in light of the legal status of selected maritime zones (including territorial sea and the regime of straits established in UNCLOS) see: L. Le 
In the context of combating piracy, especially the criminalization thereof, one should also take account of other international agreements that complement the UNCLOS regulations. In particular, it is worth mentioning the Rome Convention for the Suppression of Unlawful Acts Against the Safety of Maritime Navigation (SUA Convention) and its Protocol for the Suppression of Unlawful Acts against the Safety of Fixed Platforms Located on the Continental Shelf, concluded on 10.3.1988, ${ }^{31}$ as well as the Protocol of 14.10.2005. ${ }^{32}$ The SUA Convention does not oblige states to criminalize piracy as such. However, it does dictate that states shall recognize as offences the following acts that are committed unlawfully and intentionally by any person who:

(a) seizes or exercises control over a ship by force or threat thereof or any other form of intimidation; or (b) performs an act of violence against a person on board a ship if that act is likely to endanger the safe navigation of that ship; or (c) destroys a ship or causes damage to a ship or to its cargo which is likely to endanger the safe navigation of that ship; or (d) places or causes to be placed on a ship, by any means whatsoever, a device or substance which is likely to destroy that ship, or cause damage to that ship or its cargo which endangers or is likely to endanger the safe navigation of that ship; or (e) destroys or seriously damages maritime navigational facilities or seriously interferes with their operation, if any such act is likely to endanger the safe navigation of a ship; or (f) communicates

Hardy de Beaulieu, La piraterie maritime à l'aube du XXème siècle, 'Revue Générale de Droit International Public 2011, Vol. 115, No. 3, at pp. 660-670. See also A. Lelarge, op. cit., at pp. 458-460 and A. Roach, Countering Piracy off Somalia: International Law and International Institutions, 'American Journal of International Law' 2010, Vol. 104, at pp. 398-400.

31 UNTS, Vol. 1678, at p. 222. The Convention and its Protocol entered into force on 1.3.1992. The Convention has 160 state parties, the Protocol - 148 (as of 31.10.2012). The 2005 Protocol entered into force on 28.7.2010 and was ratified by 18 states (as of 31.10.2012).

${ }^{32}$ Apart from the SUA Convention it is worth to mention the International Convention against Taking of Hostages of 12.12.1979, UNTS, Vol. 1316, at p. 205 (it entered into force on 3.6.1983; as of 14.12.2012 it had 170 state parties) and the UN Convention against Transnational Organized Crime of 15.11.2000 (UNTS, Vol. 2225, p. 209; the Convention entered into force on 29.9.2003; as of 14.12 .2012 it had 173 parties). See also R. Satkauskas, Piracy at sea and the limits of international law, 'Aegean Review of the Law of the Sea and Maritime Law' 2011, Vol. 1, No. 2, at pp. 221-222 (published online: 23.4.2010). 
information which he knows to be false, thereby endangering the safe navigation of a ship; or (g) injures or kills any person, in connection with the commission or the attempted commission of any of the offences set forth in subparagraphs (a) to (f).

An offence is committed by any person that attempts to commit, abets the commission or compels other persons to commit the above mentioned acts (Article 3). ${ }^{33}$ Also, the Convention sets forth the principles on how jurisdiction towards the persons specified in Article 3 will be executed (Article 6). These acts shall be the subject of extradition agreements among state-parties to the SUA Convention (Article 11, modified by the 2005 Protocol). The 2005 Protocol extends the obligation of states to cooperate (Article 8bis). The Convention applies only "if the ship is navigating or is scheduled to navigate into, through or from waters beyond the outer limit of the territorial sea of a single State, or the lateral limits of its territorial sea with adjacent States". On the other hand, "it nevertheless applies when the offender or the alleged offender is found in the territory of a State Party other than the State referred to in paragraph 1" (Article 4).

However, Somali pirates operate from the shore and not infrequently act also in the territorial sea or even inland waters. Since Somali authorities are incapable of exercising effective jurisdiction throughout the whole territory, the provisions on piracy would - to a large degree - remain inapplicable and the perpetrators would remain unpunished. ${ }^{34}$ Hence, it became necessary to complement the strict definition of piracy with the concept of armed robbery. It refers to piracy de facto, i.e. acts of piratical in nature, but committed in territorial seas. The concept of 'armed robbery' was further elaborated on, inter alia in the context of the Somali piracy, under the auspices of the IMO. In accordance with paragraph 2.2 of the IMO Code of Practice for the Investigation of the Crimes of Piracy and Armed Robbery, concluded on 2.12.2009:35

33 The list of acts was extended on the basis of the 2005 Protocol.

34 A. Odeke, op. cit., at p. 136, characterizes Somali piracy as a 'hybrid one'. The Author underlines that the novelty of the Somali piracy is that it "includes armed robbery at sea, kidnapping, hostage taking, general security, links to terrorism, money laundering and international organized crimes".

35 Resolution A.1025(26), annex. Text available at: http://www.imo.org/OurWork/ Security/SecDocs/Documents/Piracy/A.1025.pdf. 
Armed robbery against ships" means any of the following acts:

1. any illegal act of violence or detention or any act of depredation, or threat thereof, other than an act of piracy, committed for private ends and directed against a ship or against persons or property on board such a ship, within a State's internal waters, archipelagic waters and territorial sea;

2. any act of inciting or of intentionally facilitating an act described above. ${ }^{36}$

In the context of combating armed robbery, important problem emerged - namely, that of the possibility for states and international organizations to enter Somali territorial waters in order to pursue and punish de facto pirates. In these waters, the principle of the universal jurisdiction enshrined in UNCLOS is inapplicable. The solution to this problem, with the parallel effort to retain, at least formally, the sovereignty and territorial integrity of Somalia, could only be found through the United Nations.

\section{UN Operations in Relation to Piracy between Africa and Assia, with Particular Emphasis on the Role of Regional Organizations}

\subsection{UN Security Council}

UN Security Council (UNSC) resolutions play a crucial role in preventing and countering Somali piracy. They may be subdivided into two categories. The first relates to the situation in Somalia as such. These resolutions have systemic character and concern piracy indirectly, while

36 It is not the first definition of 'armed robbery', formulated in the context of piracy, though. Such a definition is also included in Article 1 (2) of the Regional Cooperation Agreement on Combating Piracy and Armed Robbery against ships in Asia. It was signed on 11.11.2004 and it entered into force on 4.9.2006. 18 states of the region are parties to it. On the basis of the Agreement, Information Sharing Centre $z$ with its seat in Singapore, was established. See more at: http://www.recaap.org/; M. Mejia, Regional Cooperation in Combating Piracy and Armed Robbery against Ships: Learning Lessons from ReCAAP [in:] A. Petrig (ed.), 'Sea Piracy Law. Selected National Legal Frameworks and Regional Legislative Approaches', Duncker and Humbolt, Berlin 2010, at p. 127 et seq. Geographical criterion employed in the Agreement dictates to treat 'armed robbery' as acts committed ,in a place within a Contracting Party's jurisdiction over such offences”. 
they are aimed at eliminating the causes thereof by resolving Somalia's external and internal conflicts as well as by securing its long-term political and socio-economic stability. At the core of these resolutions lies the assumption that the situation in Somalia constitutes a threat to international peace and security in the region. They have been adopted (with some interruptions) since 1992. On the one hand, they introduce various sanctions (weapons embargo, sanctions concerning the transit of persons or the freezing of their assets) and, on the other hand, they contain authorizations that provide for the possibility to conduct peace operations - directly under the auspices of the United Nations or through regional security organizations. In this context it is important to draw attention in particular to the UNSC Resolution 733 (1992) of 23.1.1992, which imposed an embargo on military equipment, and to the UNSC Resolution 751 (1992) of 24.4.1992, concerning the UN Operation in Somalia. Until 2006, resolutions maintaining the sanctions regime or seeking to prosecute and punish entities that violate the embargo were predominant. ${ }^{37}$ Since 2006 resolutions of a new kind have emerged. They authorize regional organizations to conduct peace operations. Among them, UNSC Resolution 1814 (2008) of 15.5.2008 is of particular importance.

The second group of resolutions comprises those that relate specifically to Somali piracy. ${ }^{38}$ The first resolutions of this kind stem from 2008. In this context, primary importance shall be attributed to the UNSC Resolution 1816 (2008) of 2.6.2008. ${ }^{39}$ On the basis of this resolution, the UNSC authorized UN Member States, in line with the

37 UNSC Resolution 1844 (2008) of 20.11.2008 expanded the sanctions regime (inter alia, as a consequence of the increase in the number of piracy attacks) to include the restrictions in the transit of persons and the freezing of assets, especially insofar as they result from ransom, O. Elagab, op. cit., at pp. 72-74. See also UNSC Resolution 1519 (2003) of 16.12.2003 where the SC called upon, inter alia, IGAD and African Union „to establish focal points to enhance cooperation with the Monitoring Group and to facilitate information exchange" (para. 5). They were also urged to monitor and implement weapons embargo within their regional capacity (para. 9).

38 See V.P. Nanda, Maritime Piracy: How Can International Law and Policy Address This Growing Global Menace?, 'Deventer Journal of International Law and Policy' 2011, Vol. 39, No. 2, at pp. 183-187; J.-F. Leclercq, op. cit., at pp. 46-50; O. Elagab, op. cit., at pp. 64-67.

39 See the analysis of D. Guilfoyle, op. cit., at pp. 694-697. 
notification of the Transitional Federal Government to the UN Secretary General, to cooperate with the Somali Government in piracy and armed robbery at sea off the coast of Somalia - while respecting "the sovereignty, territorial integrity, political independence and unity of Somalia" and only insofar as they have the consent of the Transitional Federal Government of Somalia (para. 9), as well as bearing in mind that "the incidents of piracy and armed robbery against vessels [...] exacerbate the situation in Somalia which continues to constitute a threat to international peace and security in the region" - to "enter the territorial waters of Somalia for the purpose of repressing acts of piracy and armed robbery at sea, in a manner consistent with such action permitted on the high seas with respect to piracy under relevant international law" and to employ "all necessary means to repress acts of piracy and armed robbery" (para. 7; authorization was originally issued for 6 months and has been prolonged frequently since then). ${ }^{40}$ It shall be underlined that the SC authorized states not only to combat piracy but also armed robbery - i.e. crimes that are committed principally within Somali territory.

All states (and states only) were called upon:

to cooperate in determining jurisdiction, and in the investigation and prosecution of persons responsible for acts of piracy and armed robbery off coast of Somalia, consistent with applicable international law including international human rights law, and to render assistance by, among other actions, providing disposition and logistics assistance with respect to persons under their jurisdiction and control, such victims and witnesses and persons detained as a result of operations conducted under this resolution (para. 11).

Subsequent resolutions have frequently repeated this formulation. The Security Council also noted that the situation in Somalia is sui

40 The authorization formula contains a number of restrictions concerning: (a) the identity of states that are entitled to act; (b) the consent of the Transitional Federal Government; (c) the requirement to act in accordance with international law and (d) the methods of combating pirates (see explanations by D. Guilfoyle, op. cit., at pp. 695-696). Taking into account, however, that the Federal Government did not have full control, the restriction, on the basis of which a state shall have its consent, is of limited value. 
generis in character and may not be considered "as establishing customary international law" (para. 9). ${ }^{41}$

The Security Council, in its Resolution 1838(2008) of 7.10.2008, called upon states whose naval vessels and military aircraft operate on the high seas and airspace off the coast of Somalia, to use "the necessary means, in conformity with international law, as reflected in the Convention [UNCLOS - C. M.], for the repression of acts of piracy" (para 3). Importantly, Resolution 1838 refers, for the first time, to regional organizations as entities that should engage in piracy. States and regional organizations were called upon to coordinate their efforts aimed at piracy on the high seas and airspace, to "cooperate with the TFG in the fight against piracy and armed robbery at sea in conformity with the provisions of resolution 1816 (2008)", and "to continue to take action to protect the World Food Programme [WFP] maritime convoys" (para. 7).

UNSC Resolution 1846 (2008) of 2.12.2008 is also of crucial importance. ${ }^{42}$ The Security Council welcomed the initiatives by some states and regional organizations to counter piracy off the coast of Somalia, including by escorting vessels of the WFP (para. 6). It called upon States and regional organizations to:

(1) coordinate, including by sharing information through bilateral channels or the United Nations, their efforts to deter acts of piracy and armed robbery at sea off the coast of Somalia in cooperation with each other, the IMO, the international shipping community, flag States, and the TFG (para. 7); (2) to take part actively in the fight against piracy and armed robbery at sea off the coast of Somalia, in particular, consistent with this resolution and relevant international law, by deploying naval vessels and military aircraft, and through seizure and disposition of boats, vessels, arms and other related equipment used in the commission of piracy and armed robbery off the coast of Somalia, or for which there is reasonable ground for suspecting such use (para. 9).

41 This reservation was introduced in particular due to the concerns of Indonesia according to which the regulations adopted in the resolutions could lead to modification or redefinition of UNCLOS. See D. Guilfoyle, op. cit., at p. 697.

42 According to A. Lelarge, op. cit., at p. 453, it was while discussing this resolution that enabled to bring into light the relations between the situation in Somalia and piracy. 
The Security Council, also for the first time, extended the authorization to enter the territorial waters of Somalia and repress piracy and armed robbery to include also regional organizations cooperating with the TFG to that aim. Moreover, this resolution called upon states not only to cooperate in establishing jurisdiction and in the investigation and prosecution of persons responsible for acts of piracy and armed robbery, but also "to build judicial capacity for the successful prosecution of persons suspected of piracy and armed robbery at sea off coast of Somalia" (paras 14 and 15).

The role of regional organizations was elaborated on in the UNSC Resolution 1851 (2008) of 16.12.2008. Apart from calling upon states, regional and international organizations to engage actively in countering piracy and armed robbery, in particular "by deploying naval vessels and military aircrafts and through seizure and disposition of boats, vessels, arms and other related equipment used in the commission of piracy and armed robbery at sea off the coast of Somalia, or for which there are reasonable grounds for suspecting such use" (para. 2), the Security Council authorized, inter alia, states and regional organizations:

[t]o conclude special agreements or arrangements with countries willing to take custody of pirates in order to embark law enforcement officials ("shipriders") from latter countries [...] to facilitate the investigation and prosecution of persons detained as a result of operations conducted under this resolution for acts of piracy and armed robbery at sea off the coast of Somalia, provided that the prior consent of the TFG is obtained for the exercise of third state jurisdiction by shipriders in Somali territorial waters and that such agreements or arrangements do not prejudice the effective implementation of the SUA Convention (para. 3). ${ }^{43}$

43 The authorization of the SC that was included in the Resolutions 1846(2008) and 1851(2008) was prolonged on the basis of Resolution 2020(2011) of 22.11.2011. Independently of the obligation to cooperate in the investigation and prosecution of pirates, the Security Council obliged UNCLOS parties (hence also the European Union) and SUA Convention parties to implement their obligations, especially with regard to criminalizing acts of piracy in their internal laws "to build judicial capacity for the successful prosecution of persons suspected of piracy and armed robbery at sea off the coast of Somalia", in accordance with international law and in cooperation with UNODC, IMO as well as with other states and international organizations. See UNSC Resolutions 1918 (2010) of 27.4.2010, para. 2, and 1950 (2010) of 24.11.2010, para. 19. See more 
The Security Council encouraged states and regional organization also to establish "an international cooperation mechanism to act as a common contact point between and among states, regional and international organizations on all aspects of combating piracy and armed robbery at sea off Somalia's coast" (para. 4). ${ }^{44}$

It is also worth drawing attention to the UNSC Resolution 1976 (2011) of 11.4.2011. The Security Council, for the first time, asked states and regional organizations to support:

[s] ustainable economic growth in Somalia, thus contributing to a durable eradication of piracy and armed robbery at sea off coast of Somalia, as well as other illegal activities connected therewith, in particular in priority areas recommended by the Istanbul conference on piracy in Somalia (para. 5).

States and regional organizations were called upon:

[t]o continue their support and assistance to Somalia in its efforts to develop national fisheries and port activities in line with the Regional Plan of Action, and in this regard emphasizes the importance of the earliest possible delimitation of Somalia's maritime spaces in accordance with the Convention [UNCLOS - C.M.] (para. 6).

The Council also called upon "States and regional organizations cooperating with the TFG in the fight against piracy off the coast of Soma-

on this subject: M. Saiful Karim, Is There an International Obligation to Prosecute Pirates?, 'Netherlands International Law Review' 2011, Vol. LVIII, No. 3, at pp. 391 et seq.; O. Elagab, op. cit., at pp. 67-69.

44 On this basis Contact Group on Piracy off the Coast of Somalia was formed. Its inaugural meeting was held on 14.1.2009 in New York. Since then, the meetings have been held regularly, on a quarterly basis. In January 2010, the Group agreed to establish a trust fund with a purpose of financing projects concerning the prosecution of piracy suspects. See V.P. Nanda, op. cit., at pp. 195-196; J.A. Roach, op. cit., at p. 413. The work of the Group is divided into 5 working groups. See also: http://www.state.gov/t/pm/ $\mathrm{ppa} / \mathrm{piracy} / \mathrm{contactgroup} /$ index.htm on the initiative of the Working Group 1 the Somali Contact Group on Counter-piracy was established (in 2010). Among its participants were the representatives of the TFG, Puntland and Somaliland (so called Kampala Process). Secretariat support to the Contact Group is provided for by the UN Political Office for Somalia. See also: http://oceansbeyondpiracy.org/matrix/activity/kampala-process. 
lia to further increase their coordination to effectively deter, prevent and respond to pirate attacks, including through the CGPCS" [Contact Group - C.M.] (para. 9). States, regional organizations and other entities were:

[t]o provide all necessary technical and financial support to the implementation of the Djibouti Code of Conduct, the Regional Plan of Action for Maritime Security in Eastern and Southern Africa and the Indian Ocean agreed by Ministers in Mauritius in October 2010 (para. 11; see more on this subject in part 5 of this paper).

The Security Council moreover recognized that piracy is a crime subject to universal jurisdiction (para. 14). It invited states and regional organizations to assist Somalia and other states of the region "in strengthening their counter-piracy law enforcement capacities, including implementation of anti-money-laundering laws, the establishment of Financial Investigation Units and strengthening forensic capacities, as tools against international criminal networks involved in piracy" and emphasized "the need to support the investigation and prosecution of those who illicitly finance, plan, organize, or lawfully profit from pirate attacks off the coast of Somalia" (para. 17). Finally, states, UNDOC and regional organizations were requested to "consider consistent with applicable rules of international human rights law, measures aimed at facilitating the transfer of suspected pirates for trial, and convicted pirates for imprisonment, including through relevant transfer agreements (...)" (para. 20).

\subsection{Other Organs of the United Nations}

Other organs and structures of the United Nations also play a role in countering Somali piracy. Firstly, the actions of the Secretary General should be noted. They have an implementing and analytical-operational character and are mostly related to the actions taken by the Security Council. These actions by the Secretary General usually take the form of reports prepared for the Security Council. In this context, especially the following reports (except for reports on "Oceans and the law of the sea"45), pre-

45 Full list available at: http://www.un.org/Depts/los/piracy/piracy_documents.htm. 
pared in 2009 in response to UNSC Resolution 1846 (2008), ${ }^{46}$ are worth mentioning: Report on the modalities for the establishment of specialized Somali anti-piracy courts of $15.6 .2011,{ }^{47}$ Report on possible options to further the aim of prosecuting and imprisoning persons responsible for acts of piracy and armed robbery at sea off the coast of Somalia of 27.7.2010 48 and Report on specialized anti-piracy courts in Somalia and other States in the region of 20.1.2012, ${ }^{49}$ as well as a letter of 23.3.2012 addressed to the President of the Security Council, annexed to which there is a Compilation of information received from Member States on measures they have taken to criminalize piracy under their domestic law and to support the prosecution of individuals suspected of piracy off the coast of Somalia and imprisonment of convicted pirates. ${ }^{50}$ The United Nations Political Office for Somalia (UNPOS), ${ }^{51}$ established by the UNSC Resolution 1863 (2009) on the basis of a proposal of the Secretary General, is yet another entity that deploys efforts to establish lasting peace and stability in Somalia, including by restoring, training and maintaining the Somali security forces and, via such means, contributes to the eradication of the root-causes of Somali piracy.

One shall also highlight the actions undertaken by United Nations Office on Drugs and Crime (UNODC). The Office, in 2009, initiated a programme that aimed to support Kenya (and currently also: the Maldives, Mauritius, Seychelles, Somalia and Tanzania) in countering increasingly frequent piracy attacks. In this framework, the UNODC provides expert, training, financial and technical assistance as regards conducting penal proceedings, including the transfer of suspects with a view to putting them on trial and the means of carrying out the punishment (enhancing the standard of prisons). The Office cooperates, inter alia, with the Contact Group. ${ }^{52}$

46 S/2009/146 and S/2009/590.

$47 \mathrm{~S} / 2011 / 360$.

48 S/2010/394.

$49 \mathrm{~S} / 2012 / 50$.

50 S/2012/177. The Compilation is a means of implementing UNSC Resolution 2015 (2011) of 24.10.2011.

51 See: http://unpos.unmissions.org/.

52 More on that subject: http://www.unodc.org/unodc/en/piracy/index.html?ref =menuside. See also L. Ploch, Ch.M. Blanchard, R. O’Rourke, R. Chuck Mason, R.O. King, op. cit., at pp. 25-26. 


\section{International Maritime Organization Operations in Relation to Piracy between Africa and Âsia}

The International Maritime Organization undertakes numerous activities of a normative, monitoring, analytical and informative character that are aimed at providing safety and security at sea. They include combating piracy both in general, as well as piracy in-between Africa and Asia. ${ }^{53}$ As a result the IMO has, since 1984, collected and published data on maritime piracy. ${ }^{54}$ In 1998 it started its first long-term project on piracy. In 2004 the IMO, facing the problems in the Malacca Strait, launched an initiative to protect vital shipping lanes. Furthermore, the implementation of the SUA and SOLAS Conventions which, albeit from different perspectives, aimed to provide safety and security at sea, falls within the IMO's scope of interests. The Maritime Safety Committee monitors whether states abide by the maritime safety standards. Among important examples of IMO activities in relation to maritime piracy one can name the following: the Code of Practice for the Investigation of the Crimes of Piracy and Armed Robbery of 2.12.2009, which establishes standards governing the conduct of states when prosecuting pirates (legislation, international agreements, training of persons that conduct investigations, investigation strategy, the behaviour of the ship's crew upon pirate attack, investigation $)^{55}$ and a Circular letter concerning information and guidance on elements of international law relating to piracy of 17.5.2011 $1^{56}$ that provides incentives and information.

Beginning with the IMO Assembly Resolution A.979(24) of 23.11.2005, the IMO intensified its efforts against Somali piracy. It is,

53 See: http://www.imo.org/OurWork/Security/PiracyArmedRobbery/Pages/Default. aspx. See also: V.P. Nanda, op. cit., at pp. 187-189; J.A. Roach, op. cit., at pp. 409-411.

54 Similar activities are undertaken by International Maritime Bureau that is a specialized division of International Chamber of Commerce. In 1992 it established Piracy Reporting Centre. See: http://www.icc-ccs.org/piracy-reporting-centre.

55 The Code is annexed to the IMO Assembly, Resolution A.1025(26). Text available at: http://www.imo.org/OurWork/Security/SecDocs/Documents/Piracy/A.1025.pdf.

56 Text available at: http://www.un.org/Depts/los/piracy/circular_letter_3180.pdf. 
however, the Code of Conduct concerning the Repression of Piracy and Armed Robbery Against Ships in the Western Indian Ocean and the Gulf of Aden of 29.1.2009 (Djibouti Code) ${ }^{57}$ that may be labelled as a crucial document in that regard. It was adopted at a sub-regional meeting in Djibouti, organized on the basis of a IMO Council's decision, with relation to concerning the Protection of Vital Shipping Lanes, concerning maritime security, piracy and armed robbery against ships for States from the Western Indian Ocean, Gulf of Aden and Red Sea areas (26-29.1.2009). It was modelled on the Regional Cooperation Agreement on Combating Piracy and Armed Robbery against ships in Asia of 2004. ${ }^{58} 17$ states, including France, participated in the adoption of the Djibouti Code and another 12 (not being states of this region) had observer status. The European Commission, African Union and IGAD also had observer status. Eventually 9 states, including Somalia, signed the Code. ${ }^{59}$

The Code is not a legally binding document (it does not replace existing treaty arrangements) nor is it exclusive in character (the signatories may enter freely into other agreements, conduct other operations or enter into other forms of cooperation). The Code obliges parties to cooperate "to the fullest possible extent in the repression of piracy and armed robbery against ships" with a view towards:

57 IMO Council, 102 ${ }^{\text {nd }}$ session, C 102/14, Protection of Vital Shipping Lanes. Subregional meeting to conclude agreements on maritime security, piracy and armed robbery against ships for States from the Western Indian Ocean, Gulf of Aden and Red Sea areas, 3.4.2009, Resolution 1; available at: http://au.int/pages/sites/default/files/Djibouti_ Code_of_Conduct_0.pdf. The Code is accompanied by three resolutions concerning: cooperation and technical support, financing the workshops in the region and expressing gratitude. See: Ch. Buerger, M.S. Saran, Finding a Regional Solution to Piracy: Is the Dijbouti Process the Answer?, Piracy Studies, Academic Research on Maritime Piracy, http://piracystudies.org/2012/finding-a-regional-solution-to-piracy-is-the-djibouti-process-the-answer (publ. 18.8.2012). See also: O. Elagab, op. cit., at pp. 70-71.

58 Available at: http://www.recaap.org/Portals/0/docs/About\%20ReCAAP\%20ISC/ ReCAAP\%20Agreement.pdf. It is the first agreement of this kind globally. There are both differences and similarities between the two documents. See: M. Mejia, op. cit., pp. 131-136. See also: V.P. Nanda, op. cit., at pp. 189-192.

59 Other signatories are: Djibouti, Ethiopia, Kenya, Madagascar, Maldives, Seychelles, United Republic of Tanzania and Yemen. As of 31.10.2012, 20 states of the region are parties to the Code. See: http://oceansbeyondpiracy.org/matrix/activity/djibouti-codeconduct. 
(a) sharing and reporting relevant information; (b) interdicting ships and/or aircraft suspected of engaging in piracy or armed robbery against ships; (c) ensuring that persons committing or attempting to commit piracy or armed robbery against ships are apprehended and prosecuted; and (d) facilitating proper care, treatment, and repatriation for seafarers, fishermen, other shipboard personnel and passengers subject to piracy or armed robbery against ships, particularly those who have been subjected to violence.

The Code provides a definition of piracy and armed robbery. Its scope of application was defined as including Western Indian Ocean and the Gulf of Aden. It characterizes the means of protecting vessels (referring to international standards and practices, in particular IMO recommendations), measures to repress (separately) piracy and armed robbery, measures applicable to all cases, rules on nominating officers that would be embarked on patrol ships, on coordination and information sharing (utilizing information sharing centres), incidents reporting (in line with IMO recommendations), assistance among participants concerning persons who have committed, or are reasonably suspected of committing, piracy or armed robbery as well as concerning ships or persons that were subjected to piracy or armed robbery, review of national legislation (concerning the prosecution, conviction or extradition), settlement of disputes relating to the implementation of the Code, consultations and resolving claims.

\section{Actions Regarding Somali Piracy Undertaken by Other International Actors}

Regional integration organizations, while conducting operations towards piracy between Africa and Asia, need to take into account the fact the involvement of other international actors, acting individually or collectively. Without fully analyzing this issue, it is important to underline that these are particularly the United States and allies that are active in the region. In 2005, the United States National Maritime Security Strategy recognized that piracy constitutes a threat to international maritime safety. In 2007 it adopted a Policy for the Repression of Piracy 
and other Criminal Acts of Violence at Sea. In 2008, the Security Council approved the implementation plan on Countering Piracy off the Horn of Africa Partnership and Action Plan; Counter-Piracy Steering Group was also established. The adoption of UNSC Resolution 1816 (2008) enabled the commencement of operations. The first of these was Combined Task Force 151, which was an allied effort led by the United States. Under its auspices, a Maritime Security Patrol Area - patrolled by military vessels - was established. ${ }^{60}$

The United States also actively participated in NATO operations. ${ }^{61}$ The first of these, Allied Provider (October - December 2008), was directed at escorting World Food Programme convoys delivering humanitarian aid. In March 2009 another operation, Allied Protector, began (it ended in June 2009). Its aim was to counter piracy attacks against ships sailing in the region. In August 2009, operation Ocean Shield was initiated which is expected to last until at least the end of $2014 .^{62}$

\section{Engagement of RSIO in Combating Piracy. Overview and Analysis}

\subsection{The Role of the European Union}

\subsubsection{General Comments}

The EU is undoubtedly one of the most involved regional integration organizations when it comes to countering piracy between Africa and Asia. Its efforts are the most developed and most universal in scope. The character of EU operations may be viewed as a derivative of the most advanced form of integration, as well as of its global aspirations, broadly defined purposes and means of external action and capacity to undertake,

60 L. Ploch, Ch.M. Blanchard, R. O’Rourke, R. Chuck Mason, R.O. King, op. cit., at pp. 22-23; M.D. Fink, R.J. Galvin, op. cit., at pp. 386-387; W.M. Reisman, B.T. Tennis, op. cit., at pp. 18-19.

61 See: V.P. Nanda, op. cit., at pp. 192-193.

62 See: http://www.shipping.nato.int/operations/OS/Pages/default.aspx. See also: L. Ploch, Ch.M. Blanchard, R. O’Rourke, R. Chuck Mason, R.O. King, op. cit., at pp. 23-24; M.D. Fink, R.J. Galvin, op. cit., at pp. 384, 385-386; W.M. Reisman, B.T. Tennis, op. cit., at p. 19. 
in the international arena, actions that are political, normative (e.g. concluding international agreements) and operative in character. Similarly, as in the case of the United Nations, the EU's approach towards piracy is twofold.

On the one hand, the EU adopts regulatory measures that concern Somalia as such and the conflicts therein. This was supposed to change the status of Somalia as a failed state and, thereby, eliminate the structural causes of piracy in that region. In that context, the EU supports the interim federal institutions of Somalia, actions conducted by other international organizations (inter alia in the framework of the Contact Group) and the African Union mission AMISOM (see point 8.3 of this paper). From the perspective of countering piracy, these actions may be characterized as being generally preventive in character.

On the other hand, the EU's activity is aimed directly at combating and preventing maritime piracy. These actions are of political, regulative and operational in character. The European Union also undertook integrated actions where combating piracy constituted only a part thereof. Bearing in mind the internal specificity of the EU, it should also be noted that its actions may be considered both in the framework of common external and security policy (missions and operations, some systemic measures) as well as of other kinds of external action (e.g. restrictive measures).

\subsubsection{The Crystallization of the EU Position Regarding Maritime Piracy}

The approach of the EU with regard to piracy off the coast of Somalia took shape in a pragmatic way, more often than not, on an ad hoc and tactical basis, taking into account how the situation in Somalia unfolded. Nevertheless, this approach may be summarized as follows: (1) Somali piracy is not an autonomous phenomenon and its root-causes have deeper and structural character; (2) since the problem of piracy is multidimensional, it requires a holistic approach; (3) Somali piracy is viewed as a form of organized criminal activity that is similar, but not identical, to terrorism; (4) while undertaking anti-piracy operations it is crucial to prosecute and punish persons suspected of piracy.

It cannot be denied that piracy off the coast of Somalia has structural character and its roots do not allow it to be viewed as a crime committed for the simple desire of financial gain. This means, therefore, 
that the permanent elimination of piracy requires that actions be taken both with regard to countering piracy as such, as well as to determining, most of all, the root-causes of piracy and their eradication. This conclusion was also confirmed by the European Union. It was expressed, inter alia, in the Council's conclusions on Somalia, where a strong link between the situation in Somalia and the region and the intensity and scope of activities of pirates was underlined. The conclusions also point to the need to take actions regarding Somalia as such - e.g. enhancing the rule of law, the security sector, economic development, humanitarian situation, supporting federal institutions of Somalia and the African Union mission AMISOM, or actions taken by other actors concerning Somalia. ${ }^{63}$ In its conclusions of 15.9.2008 the Council confirmed "its commitment to a comprehensive approach to a lasting settlement of the Somali crisis, covering its political, security and humanitarian aspects". It also declared, in that context, its engagement in the peace process and implementation of Djibouti Agreement, its support directed at the forming of federal security forces and AMISOM. Moreover, it declares - as a means for implementing UNSC Resolutions 1814 and 1816 and countering piracy and armed robbery - the will to establish special coordination unit "with a task of supporting the surveillance and protection activities carried out by some Member States off Somali coast". Consequently, the Council approved the plan implementing a military coordination action and announced the potential establishment of naval operation. ${ }^{64}$ In the Council conclusions of 21.3.2011, in turn, the Council underlined that „[c] ontainment at sea will be further strengthened by efforts to tackle the root of piracy, focused on improving livelihoods, economic opportunities and the rule of law". ${ }^{65}$

63 In the literature on this subject, it has been underlined almost unanimously from the beginning, that the efficiency of combating piracy depends upon stabilizing the political situation in Somalia. See: A. Cudennec, Terrorisme et piraterie maritimes: L'UE affirme son statut d'acteur maritime international, 'Revue du Marché commun et de l'Union européenne' 2009, No. 532, at pp. 605-607.

64 See e.g. Council conclusions on Somalia. $2888^{\text {th }}$ General Affairs Council meeting, Brussels, 15.9.2008. See also Council conclusions on Somalia, 2942 ${ }^{\text {nd }}$ General Affairs Council meeting, Brussels, 18.5.2009.

65 Council conclusions on Somalia, Extracts from $3078^{\text {th }}$ Council meeting (Foreign Affairs), Brussels, 21.3.2011. 
The European Union also recognizes that piracy is a multi-faceted problem. The Press Communiqué entitled 'The fight against piracy in the Horn of Africa' of 21.2.2012, ${ }^{66}$ notes that "piracy is a complex issue that can only be overcome by combining political and diplomatic efforts with military and legal action, development assistance and strong international coordination". Consequently, the EU's approach does not boil down to merely conducting military operations. Notwithstanding operational actions (currently: mission EUNAVFOR Atalanta), the EU undertakes international judicial cooperation, supports regional maritime capacities, provides assistance and conducts dialogue in order to stabilize the situation in Somalia. The complexity of Somali piracy and the fact that it impacts upon the situation in the entire region, or even globally, requires the adoption of a universal approach, also in terms of international actors (at an international level, in particular under the auspices of the United Nations, regional and sub-regional, and also between these various levels). The European Union sees a clear need to coordinate their activities. In this regard, operational cooperation, political coordination or (co)organizing of international conferences may come into play. ${ }^{67}$

The need to adopt a holistic approach towards piracy finds its expression not only in documents referring strictly to that phenomenon but also in documents that are more general in character. In the latter case, it is worth considering 'A Strategic Framework for the Horn of Africa' adopted by the Council on 14.11.2011. ${ }^{68}$ The aim of the Strategic Framework is "to support the people of the region in achieving greater peace, stability, security, prosperity and accountable government". One of the means of to attain this is to ensure that "the insecurity in the region does not threaten the security of others beyond its borders, e.g. through piracy, terrorism or irregular migrations". Strategic Framework considers that the emergence of piracy is one of the consequences of "the absence

66 Doc. A 71/12. Its updated version was released in June 2012.

67 As an example of conference activities one can point out to the High Level Ministerial Conference on Maritime Piracy of 2010, organized in collaboration with the Indian Ocean Commission.

68 Document annexed to the Council conclusions on the Horn of Africa, 3124th Foreign Affairs Council meeting, Brussels, 14.11.2011. For the purposes of the Strategy, Horn of Africa is understood as including states-members of IGAD, i.e. Djibouti, Eritrea, Ethiopia, Kenya, Somalia, Sudan, South Sudan and Uganda. 
of the rule of law or an administrative vacuum" in Somalia. It is an example of organized criminal activity "that threatens economic activity not just in the region but world-wide", which results from the insecurity in the region. Hence, piracy is treated as pars pro toto. In this context, it is stated that the following measures are required with regard to piracy: (1) support for the implementation of the Dijbouti Code of Conduct; (2)active support for regional maritime and judiciary capacity building; (3) regional engagement and coordination with the IMO to make operational the ESA/IO counter-piracy strategy and action plan; (4) the conclusion of transfer agreements with third countries willing to accept the transfer of piracy suspects captured by Operation Atalanta; (5) contribution to the implementation of UNSC Resolution 1976, particularly with a view to finding a permanent solution to the judicial treatment of piracy suspects and investigating the financial flows of piracy profits that will lead to the identification of the instigators of piracy; (6) coordinating with partners through the Global Counter-Terrorism Forum on the capacity building measures and counter-radicalisation in Somalia and Yemen and on regional counter-terrorism measures in Kenya and Uganda. The European Union also declared that it will enhance its partnership with, inter alia, regional and international organizations, in particular with the African Union, the United Nations but also with COMESA, EAC and IGAD with regard to regional cooperation, as well as with the IMO, UNODC, INTERPOL, EUROPOL, Contact Group and, where appropriate, NATO with regard to countering piracy and rule of law cooperation.

For the EU, the Somali piracy constitutes a form of organized crime. The aforementioned Press Communiqué entitled 'The fight against piracy in the Horn of Africa' states that "[p]iracy has to be understood as organized crime that is happening on land and at sea with kidnapping crews and ships for ransom as the business model". At the same time, piracy is not to be deemed as constituting terrorist activity. ${ }^{69}$ This is further confirmed

69 However, the secondary law of the EU approaches piracy and terrorism in a homologous way. See the definition of terrorism in Article 1 of the Council framework decision No. 2002/475/JHA of 13.6.2002 on combating terrorism, O.J. 2002, L 164, p. 3, according to which terrorism includes 'attacks upon person's life which may cause death, attacks upon physical integrity, kidnapping or hostage taking, seizure of ships'. Consolidated text available at: http://eur-lex.europa.eu/LexUriServ/LexUriServ.do?uri=C ONSLEG:2002F0475:20081209:EN:PDF. See also: A. Cudennec, op. cit., at pp. 600-602. 
by the Joint Communication on EU Counter-terrorism Action Plan for the Horn of Africa and Yemen (which is a document implementing the abovequoted Strategic Framework), which was presented to the Council by the Commission and the High Representative on 31.8.2012.

According to the European Union, it is of fundamental importance to prosecute, seize and punish pirates. The Council underlined in its conclusions on Somalia of 21.3.2011 that the two crucial elements of anti-piracy operations are: prosecution and detention ${ }^{70}$. However, given the specificity of the piracy phenomenon, in particular given the existence of criminal networks, it is important not only to capture the perpetrators but, above all, the piracy network leaders, financiers and instigators.

\subsubsection{EU Operations Concerning Somalia}

\section{A. Restrictive Measures Concerning Somalia}

The first steps that the EU took with regard to Somali piracy should be considered as implementing the UNSC sanctions that introduced a weapons embargo and restrictions on military activities. Notwithstanding the fact that such resolutions date back to the 1990s, their EU implementation was only effected by the Council Common Position 2002/960/CFSP of 10.12.2002 concerning restrictive measures against Somalia. ${ }^{71}$ As a legal basis for that Common Position, the Council referred to UNSC Resolution 733 (1992) and subsequent Resolutions 751 (1992), 1356 (2001) and 1425 (2002). This act was in turn implemented through Council Regulation No 147/2003 of 27.1.2003 concerning restrictive measures in respect of Somalia. ${ }^{72}$ However, it should be noted that, whereas in the preamble to the Common Position the Council "affirmed its continuing support to the Intergovernmental Authority on Development (IGAD) resolutions of 24.11.2000 and 11.1.2002 which provide a general framework for the Somali reconciliation process", the Regulation 147/2003, as amended in 2007 following the need to implement the UNSC Resolution, provides for a clear exception (Article 2a) in relation to:

70 Council conclusions on Somalia, Extracts from $3078^{\text {th }}$ Council meeting (Foreign Affairs), Brussels, 21.3.2011.

71 O.J. 2002, L 334, p. 1.

72 O.J. 2003, L 24, p. 2 with subsequent changes. 
[t]he provision of financing, financial assistance, technical advice, assistance or training related to military activities, if it has determined that such financing, advice, assistance or training is intended solely for the support of or use by the AMISOM mission referred to in paragraph 4 of United Nations Security Council Resolution 1744 (2007).

This signifies that the European Union took heed of, and positively assessed, the activities undertaken by African integration organizations in Somalia.

The situation with regard to the more up-to-date restrictive measures adopted by the EU presents itself in a similar way. On 26.2.2009, the Council adopted Common Position 2009/138/CFSP concerning restrictive measures against Somalia, repealing Common Position No. 2002/960/ /CFSP. ${ }^{73}$ On this occasion, the Council acted in order to implement UNSC Resolution 1844 (2008). It maintained the exception, with regard to restrictions imposed in UNSC Resolution 1744 (2007), for AMISOM and introduced such an exception for regional organizations that took measures in accordance with UNSC Resolutions 1851 (2008) and 1846 (2008) (Article 1 (3) (a)). Moreover, the Council implemented sanctions

[a]gainst persons and entities designated by the Sanctions Committee as engaging in or providing for acts that threaten the peace, security or stability of Somalia, including acts that threaten the Djibouti Agreement of 18.9.2008 or the political process, or threaten the TFIs or AMISOM by force; as having acted in violation of the arms embargo and related measures as referred to in Article 1; as obstructing the delivery of humanitarian assistance to Somalia, or access to, or distribution of, humanitarian assistance in Somalia (Article 2).

The Council moreover introduced an embargo for weapons and military equipment, for the provision of any assistance for persons or entities referred to in Article 2 of the Common Position, restrictions concerning the entry into or transit through the Member States' territories

73 O.J. 2009, L 46, p. 73 with subsequent changes. See also Council decision 2010/231/CFSP of 26.4.2010 concerning restrictive measures against Somalia and repealing Common Position No. 2009/138/CFSP, O.J. 2010, L 105, p. 17. Denmark did not participate in adoption of this decision. 
of these persons or entities, and sanctions concerning the freezing of all funds and economic resources owned by such persons or entities. The sanctions concerning some of those persons or entities were expanded in the Council Regulation (EU) No 356/2010 of 26.4.2010 imposing certain specific restrictive measures directed against certain natural or legal persons, entities or bodies, in view of the situation in Somalia. ${ }^{74}$

\section{B. EUTM Mission in Somalia}

In 2010, the European Union decided to adopt a more systemic approach with regard to Somalia. The foundation thereof was the Council decision 2010/96/CFSP of 19.2.2010 on a European Union military mission to contribute to the training of Somali security forces. ${ }^{75}$ This decision in fact implemented UNSC Resolution 1872 (2009) of 26.5.2009. The latter underlined "the importance of the re-establishment, training, equipping and retention of Somali security forces" and recommended that UN Member States, regional and international organizations offer "technical assistance and equipping of the Somali security forces" (point 1, preamble of the Council decision). The basic purpose of the mission was to strengthen the Somalia Transitional Federal Government. In particular, it aimed at contributing to

[t]he development of the Somali security sector through the provision of military training to the National Security Forces (NSF). Training will focus on developing Command and Control and specialised capabilities and on self-training capacities of the Somali NSF, with a view to transferring EU training expertise to local actors. EUTM Somalia will continue operating in close cooperation and coordination with other actors in the International Community, in particular the United Nations, AMISOM, and the United States of America and Uganda in line with agreed TFG requirements (Article 1 (1)).

The mission had its headquarters mainly in Uganda and, partially, also in Kenya (Nairobi) and Brussels (Article 1 (2)). In accordance with

O.J. 2010, L 105, p. 1 with subsequent changes.

75 O.J. 2010, L 44, p. 16 with subsequent changes. Consolidated version available at: http://eur-lex.europa.eu/LexUriServ/LexUriServ.do?uri=CONSLEG:2010D0096:20110728 :EN:PDF. 
Article 8 of the decision, third states may participate in the military operation. States making significant military contributions to the EU military mission are invited to participate in the Committee of Contributors. The EUTM Mission Somalia was initiated on 7.4.2010 on the basis of the Council decision No. 2010/197/CFSP of 31.3.2010. ${ }^{76}$ Denmark does not participate in the said mission. The Committee of Contributors was established on the basis of the Political and Security Committee decision EUTM Somalia/2/2011 of 8.9.2011. ${ }^{77}$ Currently, the only participating third state is Serbia. ${ }^{78}$

Legal writings on the subject took account of three important problems: (1) "Somalia needs a totally new set of security structures, the training of soldiers is the last step that needs to be taken". That, in turn, depends on stabile internal political system, including the government; (2) security forces are selected and trained by the Federal Government. Hence, they will only support that Government whereas they should serve the whole society; (3) EUTM is not present in Somalia and therefore is not in a position to assess the results of EU actions. ${ }^{79}$ Only in respect of the first of the aforementioned issues does any hope emerge, following the elections in Somalia, that the situation will gradually become more stable.

\subsubsection{The European Union Actions Directed Strictly Against Piracy}

\section{A. EU NAVCO and EU NAVFOR Atalanta Missions}

EU NAVCO was the first operational action of the EU relating to countering piracy in the Horn of Africa. It was established on the basis of Council Joint Action No. 2008/749/CFSP of 19.9.2008 on the European Union military coordination action in support of UN Security Council resolution 1816(2008) (EU NAVCO). ${ }^{80}$ As one may deduce from the title of that act, the primary purpose of this action was to contribute to implementation of the UNSC Resolution 1816 (2008). Operation EU

76 O.J. 2010, L 87, p. 33.

7 O.J. 2011, L 324, p. 34.

78 See the Political and Security Committee decision EUTM Somalia/1/2011 of 6.12.2011 which approved the participation of Serbia in the mission, O.J. 2011, L 324, p. 36.

79 H.-G. Ehrhart, K. Petretto, op. cit., at pp. 281-282.

80 O.J. 2008, L 252, p. 39. 
NAVCO had a military and coordination character. Its aim was to support "the activities of Member States deploying military assets in theatre, with a view to facilitating the availability and operational action of those assets, in particular by setting up a coordination cell in Brussels" ("EU Coordination Cell'; Article 1 para. 1). The Coordination Cell became, within the framework of the EU mission, a focal point for EU-UN relations. Moreover, at an operational level, the mission was supposed to establish contacts with shipowners' organizations, UN departments, World Food Programme, the International Maritime Organization and Combined Task Force $150^{81}$ (Article 9). The mission is open for participation by third states (Article 10).

The duration of the EU mission was not limited in time. The Council's decision only stated that military coordination action "shall terminate on a date to be decided by the Council and shall be reassessed at the end of the period of validity of UN Security Council resolution 1816(2008)" and the Joint Action shall be repelled on the date of the closing-down of the EU Coordination Cell (Article 14 para. 2). In practice, the Joint Action was repelled as soon as new, more wide-ranging EU mission was established - EU NAVFOR Atalanta. It has become the first, and so far the only, EU naval military mission.

The legal basis for the mission is the Council Joint Action 2008/851/ CFSP of 10.11 .2008 on the European Union military operation to contribute to the deterrence, prevention and repression of acts of piracy and armed robbery off the Somali coast ${ }^{82}$. Denmark does not participate in the mission. Atalanta has a typically implementing character and, as such, provides an example of a holistic approach. ${ }^{83}$ It implements

81 The coalition of 25 states has its seat in Bahrain. It was established in order to control, in relation to countering piracy and the situation at the Horn of Africa (especially in the period 2006 - 2009, inter alia in connection to the need to securing WFP convoys transporting food to Somalia), suspected ships. In this latter case, Operation Enduring Freedom is also of relevance.

82 O.J. 2008, L 301, p. 33, Corr. O.J. 2009, L 253, p. 18 with subsequent changes. Last consolidated version available at: http://eur-lex.europa.eu/LexUriServ/LexUriServ. do?uri=CONSLEG:2008E0851:20120323:EN:PDF.

83 See: H.-G. Ehrhart, K. Petretto, The EU, the Somalia Challenge, and Counter-piracy: Towards a Comprehensive Approach?, 'European Foreign Affairs Review' 2012, Vol. 17, No. 2, at pp. 269-272. 
a number of UNSC resolutions. Consequently, the current version of Article 1 para. 1 of the Joint Action formulates the main objectives of the mission as follows:

1. The European Union (EU) shall conduct a military operation in support of Resolutions 1814 (2008), 1816 (2008), 1838 (2008), 1846 (2008) and 1851 (2008) of the United Nations Security Council (UNSC), in a manner consistent with action permitted with respect to piracy under Article 100 et seq. of the United Nations Convention on the Law of the Sea signed in Montego Bay on 10 December 1982 (hereinafter referred to as "the United Nations Convention on the Law of the Sea") and by means, in particular, of commitments made with third States ("Atalanta") in order to contribute to: 1) the protection of vessels of the WFP delivering food aid to displaced persons in Somalia, in accordance with the mandate laid down in UNSC Resolution 1814 (2008), and 2) the protection of vulnerable vessels cruising off the Somali coast, and the deterrence, prevention and repression of acts of piracy and armed robbery off the Somali coast, in accordance with the mandate laid down in UNSC Resolutions 1846 (2008) and 1851 (2008).

The territorial scope of the EU mission Atalanta was extended. Initially, naval forces could operate up to $500 \mathrm{~nm}$ off the coastline of Somalia and neighbouring states whereas, currently, those forces may operate in "the Somali coastal territory and internal waters, and the maritime areas off the coasts of Somalia and neighbouring countries within the region of the Indian Ocean" (Article 1 para 2).

The exact objectives of the mission are set in Article 2 of the Joint Action. Their scope was extended in parallel to the subsequent decisions of the Council. At the risk of oversimplification, one may enumerate the following objectives: (1) providing security to "to vessels chartered by the WFP, including by means of the presence on board those vessels of armed units of Atalanta, including when sailing in Somalia's territorial and internal waters"; (2) when needed, providing security "to merchant vessels cruising in the areas where it is deployed"; (3) to "keep watch over areas off the Somali coast, including Somalia's territorial and internal waters, in which there are dangers to maritime activities, in particular to maritime traffic"; 4) to "take the necessary measures, including the use of force, to deter, prevent and intervene in order to bring to an end acts of 
piracy and armed robbery which may be committed in the areas where it is present"; 5) seizing, arresting and transferring individuals suspected of "intending [...] to commit, committing or having committed acts of piracy or armed robbery in the areas where it is present and seize the vessels of the pirates or armed robbers or the vessels caught following an act of piracy or an armed robbery and which are in the hands of the pirates or armed robbers, as well as the property on board"; 6) maintaining links with various actors in the region with relation to countering acts of piracy and armed robbery, and in particular with the naval forces of Combined Task Force 151; 7) providing assistance to Somali authorities through making the data concerning fisheries, obtain during the operations, available, as long as sufficient progress in the area of maritime capacitybuilding is obtained; 8) collecting data concerning individuals enumerated in point 5 above that would allow for the identification of those persons and transmitting selected information, in accordance with concluded agreements, to National Central Bureau of the INTERPOL located in the Member State where the Operational Headquarters is stationed.

The obligation to attain these objectives by Atalanta is not absolute, since it was qualified by the "as far as available capabilities allow" clause (Article 2 in capite). Whilst all EU Member States other than Denmark are bound by the decision, it does not oblige them to directly participate in the operational activities of the mission. The level of engagement in the Atalanta operations differs even among those countries that decided to actively participate in it. All in all, those states participating in the mission are as follows: Belgium, France, Germany, Greece, Netherlands, Spain, Sweden, United Kingdom. ${ }^{84}$

Mission Atalanta has its headquarters in the United Kingdom (Northwood; Article 4). In accordance with Article 5, commencement of the mission was dependent on the notification of the Transitional Federal Government sent to the UN Secretary General which constituted a reply to the offer by the EU, in line with para. 7 of the UNSC Resolution 1816 (2008). Such notification was indeed given on 14.11.2008. Consequently, the EU Council adopted a decision 2008/918/CFSP on the launch of

84 See: R. Yakemtchouk, Les Etats de l'Union européenne face à la piraterie maritime somalienne, 'Revue du Marché commun et de l'Union européenne' 2009, No. 530, at p. 447. 
a European Union military operation to contribute to the deterrence, prevention and repression of acts of piracy and armed robbery off the Somali coast (Atalanta). ${ }^{85}$ On this basis, the mission began on 8.12.2008. Initially, it was planned for 12 months. However, its duration was subsequently prolonged; in accordance with the most recent regulation in that respect, it is scheduled to terminate its activities on 12.12.2014 (Article 16 para. 2).

There is a discernible approach adopted in the Joint Action 2008/851/ /CFSP as a whole to ensure that any activities undertaken on the basis thereof are in accordance with international law. Firstly, one can point out to its intention to implement UNSC resolutions and to keep Atalanta's mandate within the legal limits defined therein (Article 1; it is only on this basis that Atalanta could operate in Somalia's territorial sea). Amendments to the Joint Action were introduced principally because of the need to maintain EU regulations in harmony with new UNSC resolutions. Furthermore, the launch of the mission was linked to UNSC Resolution 1816 (2008).

Article 1 states also that the military operation shall be conducted in a manner consistent with action permitted with respect to piracy under Article 100 et seq. of the United Nations Convention on the Law of the Sea, as well as by means, in particular, of commitments made with third States. An even stronger emphasis of the desire to comply with international law is to be observed in Article 2, which highlights that Atalanta shall operate "under conditions set by the relevant international law and UNSC Resolutions 1814 (2008), 1816 (2008) and 1838 (2008)”. The mission's legal status is regulated by international agreements concluded on the basis of Article 11 of the decision (in practice the then Article 24 TEU, currently: Article 37 TEU). Among them, one should firstly draw attention to the Agreement with Somalia (signed in Nairobi on December 31, 2008) and adopted on the basis of the Council decision 2009/29/CFSP of 22.12.2008. Moreover, the EU concluded agreements with Djibouti (signed in Djibouti on 5.1.2009, concluded on the basis of Council decision No. 2009/88/CFSP of 22.12.2008), Seychelles (signed in Victoria on 10.11.2009; concluded on the basis of Council decision

85 O.J. 2008, L 330, p. 19. 
2009/916/CFSP of 23.10.2009) ${ }^{86}$. This was linked to the prior consent of these countries for the EU military forces to station in their territories. These agreements entered into force upon their signature.

The structure of the aforementioned agreements and the provisions contained therein are similar, though not identical. They concern the status of EU forces and related personnel in the territory (including the land, sea and airspace) of the host country. The agreements contain the following important elements: (1) general principles concerning the need to respect the laws of the host country and to refrain from any activities contrary to the objectives of the mission, as well as to inform the government of the host country on the number of mission personnel stationed in the territory of that state and on the identity of vessels, aircrafts and other units that operate on its territorial sea or intend to enter the ports of that state (the detailed arrangements contained in respective agreements are nuanced on that matter: the most succinct is the agreement with Somalia, whereas the most extensive provisions are to be found in the agreement with Djibouti, which requires prior and regular information being provided to its Government that would cover not only personnel but also number of persons coming into or crossing its territory; in any case that provision is aimed undoubtedly at securing the sovereignty and territorial integrity of host states); (2) the introduction of the principle of identification, i.e. persons, vehicles and everything belonging to the mission are to be identifiable as such (in case of persons they need to be in possession of passports of military identity cards and their uniforms shall be properly marked with the emblems of the mission; objects need to be marked as well; the mission is entitled to use the EU flag, as well as flags of participating EU Member States); (3) the agreements contain regulations regarding the crossing of the border of the host country as well as regarding the transport and movement within the territory of that state (the general principle here is that of the freedom of persons and vehicles of entry into and movement within that territory); (4) the mission and EUNAVFOR personnel are granted necessary privileges and immunities (their scope is very broad, particularly with respect to

86 Respectively: O.J. 2009, L 10, p. 27, O.J. 2009, L 33, p. 41, O.J. 2009, L 323, p. 12. It is interesting to note that the EU firstly concluded these agreements and signed them afterwards. 
the personnel of the mission: it includes not only personal inviolability and jurisdictional immunity; personal privileges and immunities are most extensive in the agreement with Somalia: only in this respect full immunity with respect to criminal, civil and administrative jurisdiction applies in all situations; special regulations were also devised with respect to the ways on how the bodies of the personnel of the mission are treated); (5) the commander of the EU military forces sets forth the rules on carrying uniforms and weapons; military forces are entitled to construct or reconstruct facilities or introduce other modifications that are required to fulfil the mission's objectives (this provision is absent in the agreement with Somalia and in the case of the other agreements the consent of the host state is required (Djibouti) or conduct that is in line with that state's internal law (Seychelles); EU NAVFOR is also entitled to maintain its own communication system (only in the Somalia case is this right practically unlimited); (6) receiving state is obliged to provide assistance in preparing, establishing, executing and supporting the mission (which is entitled, inter alia, to conclude contracts in the host state), as well as obligation to provide security for the EU mission outside its premises; (7) the EU mission is not liable for the death, injury, damage and loss related to operational necessities or caused by activities in connection with civil disturbances or protection of EUNAVFOR; claims in that respect shall be settled by diplomatic means (Somalia; in case of judicial proceedings initiated by third parties, it is Somalia that shall stand in lieu of EUNAVFOR in the proceedings); (8) disputes concerning the interpretation or application of the agreement shall be examined jointly by representatives of EUNAVFOR and the Host State's competent authorities; failing agreement, the dispute shall be settled exclusively by diplomatic means between the Host State and EU representatives. Both the decision and the preamble and operative part of the agreement contain unequivocal references to UNSC resolutions.

The EU mission was obliged to cooperate with various entities. However, it is the High Representative that is responsible for these contacts (Article 9). Similarly as in the case of some other EU operations, Council decision 2008/851/CFSP allows for the participation of third states (Article 10). The legal basis for such participation is provided for in separate international agreements concluded by the EU (para. 3). Those states that contribute significantly, in a military sense, to the 
mission are included in the Committee of Contributors (para. 5). This was established on the basis of the Political and Security Committee's decision ATALANTA/3/2009 of 21.4.2009. The first country that joined the mission was Norway. ${ }^{87}$ Later Croatia, Montenegro and Ukraine also became involved.$^{88}$ The exact method of cooperation between those states and the EU was regulated in bilateral agreements. The agreement with Croatia was signed on 27.7.2009 and was applied provisionally from that date (Council decision 2009/597/CFSP), ${ }^{89}$ the agreement with Montenegro on 24.3.2010 and the decision to sign and conclude it was adopted by the Council on 22.3.2010 (2010/199/CFSP). ${ }^{90}$ Norway and Ukraine cooperate with the European Union in line with principles enshrined in agreements establishing the framework for the participation of those states in the EU crisis management operations (respectively: of 3.12.2004 $4^{91}$ and 13.6.2005 $\left.{ }^{92}\right)$.

Agreements concerning participation in operation Atalanta (especially those concluded for that purpose) define the rules under which third states are entitled to participate and, most importantly, the status of their military forces (the rules concerning EU Member States that were established in agreements with Somalia and other states in the region or through unilateral statements issued by Kenya, Seychelles or other states in the region are extended to cover the military forces of those third states). Participating third states oblige themselves to assume responsibility for claims relating to the operation of their military forces and personnel during the mission. They undertake necessary legal or disciplinary measures with regard to their military forces and personnel, in accor-

87 O.J. 2009, L 112, p. 9; Addendum to the Committee's decision, O.J. 2009, L 119, p. 40. The Committee's decision to accept the contribution of Norway ATALANTA/2/2009 of 21.4.2009, O.J. 2009, L 109, p. 52.

88 Respectively: the Committee's decisions ATALANTA/5/2009 of 10.6.2009, ATALANTA/7/2009 of 2.10.2009, O.J. 2009, L 148, p. 34, O.J. 2009, L 270, p. 19, ATALANTA/1/2010 of 5.3.2010, O.J. 2010, L 83, p. 20.

89 O.J. 2009, L 202, s. 83.

90 O.J. 2010, L 88, s. 1.

91 The agreement was concluded together with agreements concerning Iceland and Romania on the basis of the Council's decision No. 2005/191/CFSP of 18.10.2004, O.J. 2005, L 67, p. 1.

92 O.J. 2005, L 182, p. 28. The agreement entered into force on 1.5.2008. 
dance with their internal laws. Simultaneously, they need to waive all potential claims vis-à-vis all states participating in the mission. The agreements on the participation of third states also envisage that persons that have committed, or are suspected of committing, piracy and are held by EUNAVFOR and may be transferred to those third states for prosecution. It is also possible to transfer property captured by the mission's military forces. The rules on such transfer are contained in a rather standard annex to those agreements (regulating, inter alia, procedural guarantees for pirates, a commitment not to sentence anyone convicted to capital punishment, issues relating to notification and documentation of legal proceedings, EUNAVFOR commitment to provide assistance for third states participating in the mission). Finally, the agreements with third states regulate practical issues, such as the handling of classified documents (EU standards apply), chain of command (subordination to national authorities, however tactical, operational and/or control over military forces and personnel command being transferred to EU Commander; Senior Military Representative acts as a mediator between EU Commander and national authorities; the former may petition for the withdrawal of the contribution of a third state), as well as financing of the contribution of third states (as a rule, third states pay their own costs). The agreements may be implemented through technical and administrative arrangements. In the event of any breach of the agreement, each party may denounce it. Potential disputes are settled via diplomatic channels.

The repression of piracy is linked invariably with seizing and prosecuting persons engaged in this activity. As a result, Council decision 2008/851/CFSP also regulates important jurisdictional questions. In accordance with Article 12 para. 1, on the basis of Somalia's acceptance of the exercise of jurisdiction by Member States or by third States and of Article 105 of United Nations Convention on the Law of the Sea, persons having committed acts of piracy or armed robbery in Somali territorial waters or on the high seas, who are arrested and detained with a view to their prosecution, and any property used to carry out such acts, shall be transferred: (a) to the competent authorities of the flag Member State or of the third State participating in the operation, of the vessel which took them captive; or (b) if this State cannot, or does not wish to, exercise its jurisdiction, to a Member States or any third State which wishes to exercise jurisdiction over the aforementioned persons and 
property. Hence, universal jurisdiction is of subsidiary character. When the aforementioned acts are committed in waters other than Somalia's, any suspected persons and property used to commit piracy or armed robbery are to be transferred, in line with the agreements with states of the region, to the competent authorities of the State concerned or, with the consent of the State concerned, to the competent authorities of another State (para. 2). The adoption of the principle of state consent and acting on the basis of an international agreement further confirms the tendency to ensure respect for international law. Importantly, the transfer conditions shall be settled in accordance with "relevant international law, notably international law on human rights, in order to guarantee in particular that no one shall be subjected to the death penalty, to torture or to any cruel, inhuman or degrading treatment" (para. 3). ${ }^{93}$

There are various forms of agreements with third states, within the meaning of Article 12, where the captured pirates may be transferred in order to be tried. In two cases (before the entry into force of the Lisbon Treaty), these are exchange of letters and in one case (post-Lisbon Treaty): an agreement. In the former instance, the parties to these arrangements are: Kenya (Council decision No. 2009/293/CFSP of 26.2.2009) ${ }^{94}$ and Seychelles (Council decision No. 2009/877/CFSP of 23.10.2009). ${ }^{95}$ The two agreements vary.

The one with Kenya relates unequivocally to international law: UNSC resolutions concerning piracy, UNCLOS (Articles 100-107) and international human rights law, especially the International Covenant on Civil and Political Rights of 1966 and the UN Convention against Torture of 1984. Such referrals are absent in the Seychelles agreement. Annexes

93 More on the obligation to respect human rights of persons suspected of piracy and armed robbery and potential responsibility of the European Union, especially as parties to European Convention on Human Rights, see: S. Piedimonte Bodini, Fighting Maritime Piracy under the European Convention on Human Rights, 'European Journal of International Law' 2011, Vol. 22, No. 3, at p. 829 et seq.; D. Guilfoyle, Counter-Piracy Law Enforcement and Human Rights, 'International and Comparative Law Quarterly' 2010, Vol. 59, No. 1, at p. 141 et seq.; A. Fischer-Lescano, L. Kreck, Piracy and Human Rights: Legal Issues in the Fight against Piracy within the Context of the European "Operation Atalanta”, 'German Yearbook of International Law' 2009, Vol. 52, at p. 525 et seq.

94 O.J. 2009, L 79, p. 47.

95 O.J. 2009, L 315, p. 35. 
to the aforementioned letters contain important elements of these agreements. Generally, it is emphasised therein that the two countries obliged themselves to accept, upon the request of EUNAVFOR, the transfer of persons detained by EUNAVFOR in connection with piracy and associated seized property by EUNAVFOR and will submit such persons and property to its competent authorities for the purpose of investigation and prosecution. EUNAVFOR, on the other hand, will transfer persons or property only to competent Kenyan law enforcement authorities. The parties committed themselves to

treat persons transferred under this Exchange of Letters, both prior to and following transfer, humanely and in accordance with international human rights obligations, including the prohibition against torture and cruel, inhumane and degrading treatment or punishment, the prohibition of arbitrary detention and in accordance with the requirement to have a fair trial.

Also, no transferred person shall suffer the death sentence and EUNAVFOR offered to provide any necessary assistance.

In the agreement with Seychelles, this country expressed its consent to accept transferred pirates, and the European Union obliged itself to provide the Republic of Seychelles with full financial, human resource, material, logistical and infrastructural assistance. Furthermore, rules governing how to proceed with pirates and their rights throughout trial were established. The EU also appended a declaration wherein it guarantees the protection of any rights that a transferred person may have under applicable domestic or international law, as well as underlining that representatives of the EU and of EUNAVFOR will be granted access to any persons transferred to the Seychelles in order to interrogate them, to see the records of any seized property or any charges against them and any significant decisions taken in the course of their prosecution and trial. Moreover, national and international humanitarian organizations are also allowed to visit persons captured during the Atalanta mission.

The third agreement was concluded with Mauritius on 14.7.2011 (Council decision 2011/640/CFSP of 12.7.2011). ${ }^{96}$ It sets forth the

96 O.J. 2011, L 254, p. 1. 
"conditions of transfer of suspected pirates and associated seized property from the European Union-led naval force and the conditions of suspected pirates after transfer". Its preamble refers to UNSC resolutions (the most important resolutions of 2008 are explicitly mentioned: 1814, 1816, 1846 and 1851, and subsequent resolutions are referred to more broadly), UNCLOS (Articles 100-107, as well as Article 110), EU Council Joint Action on the Operation EUNAVFOR Atalanta, international human right law, including the Covenant on Civil and Political Rights and the UN Convention against Torture. It is highlighted that the agreement is without prejudice to the rights and obligations of parties deriving from international agreements and other documents establishing international tribunals, including the Rome Statute of International Criminal Court.

There are three main objectives of the agreements with Mauritius: 1) the transfer of persons suspected of attempting to commit, committing or having committed acts of piracy within the area of operation of EUNAVFOR, on the high seas off the territorial seas of Mauritius, Madagascar, the Comoros Islands, Seychelles and Réunion Island, and detained by EUNAVFOR; 2) the transfer of associated property seized by EUNAVFOR from EUNAVFOR to Mauritius; 3) the treatment of transferred persons. The rule is that, on the initiative of EUNAVFOR, Mauritius may accept the transfer of persons who were deprived of their liberty by EUNAVFOR in connection with piracy, and any associated property. The aim of that transfer is to investigate and prosecute the transferred persons and property. The acceptance by Mauritius is to be given on a case-by-case individual basis while taking into account "all relevant circumstances including the location of the incident". The transfer may only be conducted with the competent law enforcement authorities of Mauritius and only after having ascertained that "reasonable prospects of securing a conviction" exist. The suspected persons are to be treated "humanely and in accordance with international human rights obligations". Torture or cruel, inhuman or degrading treatment or punishment is prohibited. The suspected persons shall have the right to a fair trial (Article 3). The agreement enumerates in detail the rules governing the treatment, pro-secution and trial of transferred persons, listing in particular procedural guarantees (Article 4). The death penalty is prohibited. The Agreement also contains provisions concerning the exchange of information pertaining to pirates deprived of their liberty and property, as well as assistance that is to be accorded to 
Mauritius by UE and EUNAVFOR in the implementation of Agreement's obligations (Articles 6 and 7).

Disputes concerning the application and interpretation of the Agreement may be settled exclusively by diplomatic means (Article 9). The application of the Agreement may be subject to implementing arrangements (Article 10) and it shall remain in force until the termination of the Operation ATALANTA (Article 11 para. 2).

The EU itself considers that, in particular, the Operation ATALANTA was a success. The Council conclusions of 27.7.2009 on Somalia ${ }^{97}$ underline that the mission plays "a leading role in international anti-piracy efforts". The typical composition of EUNAVFOR forces is as follows: surface combat vessels and 2 to 3 aircrafts. Military personnel amounting to approx. 1400 persons. The theatre of activities is around 1.5 times bigger than Europe. The practical involvement of third states in the naval operation was rather modest. However, in 2009, Norway contributed a warship, Croatia and Ukraine delegated their staff officers to Operation's Headquarters, and Montenegro and Serbia - their naval officers. Generally speaking, third states contributed to the provision of navy vessels (surface combat vessels and auxiliary ships), maritime patrol and reconnaissance aircrafts, vessel protection detachment teams as well as military staff. According to EUNAVFOR data, as of 2009, vessels involved in the operation have provided escort to 167 World Food Programme shipments and 130 AMISOM shipments. The ATALANTA forces have transferred to the competent authorities 128 pirates, 75 of whom were convicted. Within the Operation's theatre of activities, pirates have taken 5 ships and 136 persons hostage. ${ }^{98}$

\section{B. EUCAP NESTOR}

One of the European Union's newly established missions is EUCAP NESTOR. It was created on the initiative of the High Representative of

97 Council conclusions on Somalia, 2958 ${ }^{\text {th }}$ External Relations Council meeting, Brussels, 27.7.2009.

98 See: EU NAVFOR Somalia, as well as: http://www.consilium.europa.eu/uedocs/ cms_data/docs/missionPress/files/121016_Factsheet_EUNAVFOR_Somalia_v42.pdf (data as of 31.12.2012). See also the review of the mission operations by R. Yakemtchouk, op. cit., pp. 447-449, H.-G. Ehrhart, K. Petretto, op. cit., at pp. 274-278. 
the Union for Foreign Affairs and Security Policy and its legal basis is provided for by the Council decision No. 2012/389/CFSP of 16.7.2012 on the European Union Mission on Regional Maritime Capacity Building in the Horn of Africa (EUCAP NESTOR). ${ }^{99}$ This act was adopted as a result of a series of conceptual, political and monitoring activities that related to the provision of stability in the region, in particular through combating piracy off the Horn of Africa (Preamble). The mission's aim is to "to assist the development in the Horn of Africa and the Western Indian Ocean States of a self-sustainable capacity for continued enhancement of their maritime security including counter-piracy, and maritime governance". The mission concerns Djibouti, Kenya, Seychelles and Somalia, however, with the consent of appropriate authorities, it may be also extended to apply to Tanzania (Article 1).

The duration of the mission is 24 months (Article 16) and it was not authorized to "carry out any executive function". Its aims were restricted to assistance, expert, advisory and supportive-coordinative functions. According to the Council, the mission is to:

(a) assist authorities in the region in achieving the efficient organisation of the maritime security agencies carrying out the coast guard function; (b) deliver training courses and training expertise to strengthen the maritime capacities of the States in the region, initially Djibouti, Kenya and the Seychelles, with a view to achieving self-sustainability in training; (c) assist Somalia in developing its own land-based coastal police capability supported by a comprehensive legal and regulatory framework; (d) identify priority equipment capability gaps and provide assistance in addressing them, as appropriate, to meet the objective of EUCAP NESTOR; (e) provide assistance in strengthening national legislation and the rule of law through a regional legal advisory programme, and legal expertise to support the drafting of maritime security and related national legislation; (f) promote regional cooperation between national authorities responsible for maritime security; (g) strengthen regional coordination in the field of maritime capacity building; (h) provide strategic advice through the assignment of experts to key administrations; (i) implement mission projects and coordinate donations; (j) develop and conduct a regional information and communication strategy. 
EUCAP NESTOR is a mission which is civil in character. Its Commander is, by function, the Civilian Planning and Conduct Capability Director (Article 5 para. 1). The Chef is a direct supervisor of the mission, who is responsible to the Commander (Article 5 para. 1). He is supported, in implementing the aims of the mission, by the Project Cell that is responsible for the identification and implementation of EU projects undertaken by the mission. Project Cell may also "coordinate, facilitate and provide advice on projects implemented by Member States and third States under their responsibility, in areas related to EUCAP NESTOR and in support of its objective" (Article 4 para. 3; Article 6 para. 8). The status of the mission is to be settled in the international agreement concluded by the European Union. Third States may participate in the mission in line with Article 10 of the decision.

\subsubsection{Integrated Measures}

\section{A. EU Special Representative for the Horn of Africa}

The Council decision No. 2011/819/CFSP of 8.12.2011 established EU Special Representative for the Horn of Africa. ${ }^{100}$ Initially nominated till the end of June 2012, his mandate was extended until the end of June 2013. The formula "Horn of Africa" was defined as embracing Djibouti, Eritrea, Ethiopia, Kenya, Somalia, Republic of South Africa, Sudan and Uganda. Notwithstanding that the task of the Special Representative is "to contribute actively to regional and international efforts to achieve lasting peace, security and development in the region" and "to enhance the quality, intensity and impact of the EU's multifaceted engagement in the Horn of Africa", the "initial priority shall be given to Somalia and to the regional dimension of the conflict, as well as to piracy which has its root causes in the instability of Somalia" (Article 2 para. 1 and 2 of the decision). In particular as regards Somalia, the aim of the Special Representative is:

[t]hrough the coordinated and effective use of all its instruments, to promote a return for Somalia and its people to a path of peace and

100 O.J. 2011, L 327, p. 62. His mandate was extended on the basis of Council decision 2012/329/CFSP of 25.6.2012 extending the mandate of the European Union Special Representative for the Horn of Africa (O.J. 2012, L 165, p. 62). 
prosperity. To that end, the Union supports the role of the United Nations (UN) in facilitating a credible and inclusive Somali-led political process and will continue to contribute actively, together with regional and international partners, to the implementation of the Djibouti Peace Agreement and its post-transition arrangements.

Within the framework of his mandate, the Special Representative is:

[to] contribute actively to actions and initiatives leading to the implementation of the Djibouti Peace Agreement and its post-transition arrangements, supporting institution-building, the rule of law, and the establishment of capable governance structures at all levels; improving security; promoting justice, national reconciliation and respect for human rights; improving humanitarian access, especially in South-Central Somalia through appropriate advocacy activities regarding respect for international humanitarian law; and safeguarding compliance with the humanitarian principles of humanity, neutrality, impartiality and independence,

and, moreover,

[to] contribute actively to actions and initiatives leading to the implementation of the Djibouti Peace Agreement and its post-transition arrangements, supporting institution-building, the rule of law, and the establishment of capable governance structures at all levels; improving security; promoting justice, national reconciliation and respect for human rights; improving humanitarian access, especially in South-Central Somalia through appropriate advocacy activities regarding respect for international humanitarian law; and safeguarding compliance with the humanitarian principles of humanity, neutrality, impartiality and independence,

as well as to "closely follow the regional dimension of the Somali crisis, including terrorism, arms smuggling, refugee and migration flows, and maritime security, piracy and related financial flows;" (Article 3, points e-g).

As regards piracy, the Special Representative's task is:

to contribute to developing and implementing a coherent, effective and balanced Union approach to piracy originating in Somalia, encompassing all aspects of Union action, particularly in the political, security and 
development areas and to be the Union's key interlocutor on piracy for the international community, including the Eastern and Southern Africa and Indian Ocean (ESA/IO) region (Article. 2 para. 3 and 4).

The Council decided that its task, within the framework of the mandate to combat piracy, is:

[to] maintain an overview of all Union actions within the EEAS, the Commission and Member States, and maintain regular high level political contacts with the countries in the region affected by piracy originating in Somalia, the regional organizations, the UN Contact Group on Piracy off the Coast of Somalia, the UN and other key actors in order to ensure a coherent and comprehensive approach to piracy and to ensure the Union's key role in the international efforts to fight piracy. This includes the Union's active support to regional maritime capacity-building and for the judicial treatment of pirates, and ensuring that the root causes of piracy within Somalia are adequately addressed. It also includes continued support to the ESA/IO region in the implementation of its counter piracy strategy and action plan as well as the Djibouti Code of Conduct (Article 3 point h).

Among the main instruments of the Special Representative are: within the framework of promoting multifaceted, political approach of the Union towards Horn of Africa, to "advise and report on the definition of Union positions in international fora"; 2) to "maintain an overview of all activities of the Union and cooperate closely with all relevant Union delegations". In strict coordination with the appropriate EU Delegations, he shall also provide "local political guidance to the Force Commander of EUNAVFOR Atalanta, the Mission Commander of EUTM Somalia and the Head of EUCAP NESTOR", and also cooperate closely not only with local authorities but also with the United Nations, African Union, IGAD and other entities involved in the region (art. 12 para. 2 and 3); 3) undertaking activities on the spot (its seat is Mogadishu; Article 3 para. 2).

\section{B. The Support for European Union Somali Missions: EU Operations Centre} for the Common Security and Defence Policy Missions and Operation in the Horn of Africa

The EU Operations Centre for the Common Security and Defence Policy missions and operation in the Horn of Africa is one of the 
instruments supporting the activity of the European Union in the Horn of Africa, which is important both from the standpoint of providing stability in Somalia and of combating piracy. It was established on the basis of Council decision 2012/173/CFSP of 23.3.2012. ${ }^{101}$ In accordance with Article 1 of the decision, the Centre shall be activated in support, inter alia, Operation Atalanta, EUTM Somalia, and the planned civilian CSDP mission on Regional Maritime Capacity Building (RMCB). It shall provide support in the field of operational planning and conduct of missions and operations with a view to increasing efficiency, coherence and synergies. Within this framework, the EU Operations Centre shall help facilitate information exchange and improve coordination and strengthen civilmilitary synergies (Article 2 para. 1). It shall be highlighted that the Centre shall also provide support for the Crisis Management and Planning Directorate and shall be in liaison with the European Union Special Representative for the Horn of Africa (Article 2 para. 2 (d) and (f)).

\section{Measures for Self-protection and the Prevention of Piracy and Armed Robbery Against Ships}

The potential victims of piratical attacks include the ship itself, its cargo and its crew and passengers. In this context it is particularly important that self-protection and preventive measures are undertaken with regard to ships. Taking into account the increasing number of pirate attacks in the Horn of Africa, in 2009 the Maritime Safety Committee of the International Maritime Organisation formulated a series of non-legally binding circulars. The European Commission decided to implement them via a Commission recommendation of 11.3.2010 on measures for selfprotection and the prevention of piracy and armed robbery against ships $(2010 / 159 / \mathrm{EU}),{ }^{102}$ relating them at the same time to all regions affected by piracy. The recommendation is of complimentary character inter alia vis-à-vis measures undertaken within the framework of ATALANTA. The measures described in the recommendation are divided into those having general character and those that are applicable to the situation off the coast of Somalia. They were given more detailed content in the recommendation's annex which contains best management practices to deter piracy in the

101 O.J. 2012, L 89, p. 66.

102 O.J. 2010, L 67, p. 13. 
Gulf of Aden and off the coast of Somalia. The latter are supported by international industry representatives (e.g. Intertanko, ICS, Intercargo, IMB). Broadly speaking, the aim of recommended practices is "to assist companies and ships in avoiding piracy attacks, deterring attacks and delaying successful attacks". The recommendation's annex firstly describes typical attack profiles and formulates primary conclusions on that basis. More concrete recommendations concern: (1) measures of general (in particular company planning, ship's master planning) and detailed (e.g. defensive measures) planning; (2) measures relating generally to maritime transit and to situations of piratical attack, boarding or military action; (3) measures concerning post incident reporting. The first focal point in the region is, in all cases, the UK Maritime Trade Organisation Dubai (UKMTO). It shall cooperate closely with the Maritime Security Centre Horn of Africa (MSCHOA), which is a planning and coordination authority for EU-forces in the region. The entity responsible for the exchange of information between Combined Maritime Forces and commercial shipping community is the Marine Liaison Office (MARLO). The recommendation also contains also additional guidance for vessels engaged in fishing, supplementary to the best management practices to deter piracy in the Gulf of Aden and off the coast of Somalia.

\section{The Approach of the African Union and African Sub-regional Integration Organizations towards Piracy in the Horn of Africa}

\subsection{General Comments}

Combating maritime piracy on the Horn of Africa is, for obvious reasons, important for African integration organizations, in particular the African Union and those sub-regional organizations that have amongst their members those states bordering the Indian Ocean or Somalia. It is unsurprising, therefore, that the latter include especially IGAD, COMESA and EAC.

As in the case of the European Union, the activities of those organizations are influenced to a large extent by Security Council resolutions and work undertaken by the IMO. However, for economic, technical and financial reasons, they require external support when conducting operational measures. 
These organizations also display limited capabilities as regards direct conflict with pirates. In consequence, their activities focus primarily on stabilization of the situation in Somalia and on the unification/ /harmonization of, in particular, sub-regional and national laws on piracy $^{103}$. Stabilization measures were, inter alia, to contribute to the elimination of the root causes of piracy. Moreover, interested African organizations, while undertaking their respective activities in Somalia, cooperated with each other to that end.

\subsection{IGAD Peace Support Mission in Somalia (IGASOM)}

Following the escalation of the Somali conflict, the dialogue with the temporary Somali authorities was assumed by IGAD. As early as 25.10.2004, the President of the Transitional Federal Government addressed a plea to the African Union to support his government by initiating a military peace operation in Somalia. On 5.1.2005, the Peace and Security Council of the African Union approved the main targets of its support mission (AU Peace Support Mission). State Members of the IGAD expressed their readiness to send their military forces. Consequently, on 7.2.2005, the IGAD was authorized by the African Union Peace and Security Council to establish a peace support mission in Somalia. On 14.9.2006 the African Union, acting on the motion of IGAD, approved the IGAD Peace Support Mission in Somalia (IGASOM). The Deployment Plan for a Peacekeeping Mission was presented to the UN Security Council. In its resolution 1725(2006) of 6.12.2006 the UNSC stated that, on the basis of decisions by the IGAD and the African Union Peace and Security Council, the aim of its decision was to support the peace and stabilization process in Somalia "through an inclusive political process and creating the conditions for the withdrawal of all foreign forces from Somalia" (para. 1). It also explicitly authorized the IGAD and the African Union Member States "to establish a protection and training mission in Somalia" and determined its mandate on the basis of Deployment Plan for IGASOM. The Mission was established for a 6-month period (para. 3).

103 See: H. Fouché, Harmonized Legal Framework for Africa as an Instrument to Combat Sea Piracy [in:] Sea Piracy Law..., at pp. 150-158. 


\subsection{AMISOM}

The most important operation undertaken by the African organizations is the African Union Mission to Somalia (AMISOM). ${ }^{104}$ The African Union Peace and Security Council decided, in a Communiqué of 19.1.2007, ${ }^{105}$ to establish the mission, its aims, targets, scope and duration. AMISOM was granted the unequivocal authorization of the UN Security Council, in its resolution 1744(2007) of 20.1.2007. ${ }^{106}$ Such authorization was initially grated for 6 months. However, alongside developments on the ground in Somalia, it was subsequently prolonged. In one of the last resolutions in that respect, UNSC Resolution 2073 (2012) of 7.11.2012, the UN Security Council decided to prolong the mission's mandate until 7.3.2013.107 At first, AMISOM was regarded as a temporary mission, established only until the creation of a UN Peacekeeping Operation in Somalia, which AMISOM was intended to form part of. ${ }^{108}$ With time, however, the role of AMISOM was strengthened. ${ }^{109}$ This can be inferred not only due to the fact that the mission was prolonged but also in the increase, albeit not without problems, ${ }^{110} \mathrm{f}$ the number of African forces

104 See AMISOM website: http://amisom-au.org/. Generally on that operation see: A. Jeng, Peacebuilding in the African Union. Law, Philosophy and Practice, Cambridge 2012, at pp. 257-268.

$10569^{\text {th }}$ meeting of the Council. Doc. PSC/PR/Comm.(CLXIX). Text available at: http://www.securitycouncilreport.org/atf/cf/\%7B65BFCF9B-6D27-4E9C-8CD3CF6E4FF96FF9\%7D/SOMALIA\%20AUCOMMUNIQUE.pdf.

106 See also the UNSC Resolution 1814 (2008) of 15.5.2008.

107 It is interesting to note that the African Union Peace and Security Council took the decision to prolong the mission for another 12 months already in its Communique of 5.1.2012 (para. 11); doc.PSC/PR/COMM.(CCCVI). Text of the Communiqué available at: http://au.int/en/dp/ps/sites/default/files/PSC\%20306\%20Communique\%CC\%81\%20 on\%20AMISOM\%20Strategic\%20Concept-Eng-05-01-12_0.pdf.

108 See for e.g. UNSC Resolution 863 (2009) of 16.1.2009, paras 4, 8, 10.

109 In UNSC Resolution 2036 (2012) of 22.2.2012, para. 6, the Security Council, while deciding on logistical support for AMISOM and reimbursement of the costs of its contingent, it stated that it did so "owing to the unique character of the mission".

110 The Peace and Security Council draws attention to those problems in communiqués of $123^{\text {rd }}$ meeting of 29.4 .2008 , para 3 or of $139^{\text {th }}$ meeting of 29.6.2008, para. 6. See, respectively, docs PSC/PR/Comm.(CXXIII) and PSC/HSG/Comm.(CXXXIX). 
(starting with 8,000 before building up to $12,000^{111}$ and then 17,731 soldiers ${ }^{112}$, sent in particular from Uganda, Burundi and Djibouti; a small police and civil contingent was also established). The mission was also exempted from the arms and military equipment embargo introduced on the basis of the UNSC Resolution 733 (1992). The mission's status is regulated in the agreement between the Transitional Federal Government of the Somali Republic and the African Union of 6.3.2007 (which entered into force on the date of signature).Both the mission and its personnel were granted broad privileges and immunities (Articles $\mathrm{X}$ and $\mathrm{XV}$; they embrace also "members of all components of the mission including African countries, European Union, United States"; Article III). AMISOM has also legal personality (Article $V)^{113}$. The participation of individual states in the mission is regulated in separate agreements (e.g. with Djibouti of 11.7.2012).

The mission's objectives were never explicitly included the fight against piracy. The African Union Peace and Security Council designated three objectives: "(i) to provide support to the TFIs in their efforts towards the stabilization of the situation in the country and the furtherance of dialogue and reconciliation, (ii) to facilitate the provision of humanitarian assistance, and (iii) to create conducive conditions for longterm stabilization, reconstruction and development in Somalia" (para. 8; those objectives were designated in Article IV of the agreement on AMISOM's status). The UN Security Council, in its resolution 1744, agreed that the AMISOM's mandate shall include: (1) supporting dialogue and reconciliation in Somalia by assisting with the free movement, safe passage and protection of persons; (2) providing protection to the Transitional Federal Institutions to help them carry out their functions of government,

111 UNSC Resolution 2010 (2011) of 30.9.2011, para. 1. On its basis, the UNSC "encourages the United Nations to work with the African Union to develop a guard force of an appropriate size, within AMISOM's mandated troop levels, to provide security, escort and protection services to personnel from the international community, including the United Nations".

112 UNSC Resolution 2036 (2012) of 22.2.2012, para. 2.

113 Text available at: http://www.google.pl/url?sa=t\&rct=j\&q=\&esrc=s\&source=web\&c $\mathrm{d}=1$ \&ved=0CCUQFjAA\&url=http\%3A\%2F\%2Fau.int\%2FRO\%2FAMISOM\%2Fsystem\%2F files\%2FStatus_of_Mission_Agreement_on_AMISOM.pdf\&ei=qLenUOnaMI_U4QTwpoG ABQ\&usg=AFQjCNEbOl_4W3Otgw5PvfwStbeiOPIYAw. 
and security for key infrastructure; (3) assisting with implementation of the National Security and Stabilization Plan, in particular the effective re-establishment and training of all-inclusive Somali security forces; (4) contributing to the creation of the necessary security conditions for the provision of humanitarian assistance; (5) protecting the mission and its personnel (para. 4). ${ }^{114}$

AMISOM required external (financial, technical and logistical) support. The African Union Peace and Security Council, in its Communiqué of 2007, requested such coordinated support and addressed its plea to "the League of Arab States, the European Union and its member states, the United Nations, as well as other AU partners" (para. 12). In consequence, United Nations Support Office for AMISOM ${ }^{115}$ was established and the EU granted its financial and operational support. A Memorandum of Understanding among AMISOM, IGAD Office of the Facilitator for Somalia Peace and National Reconciliation and UN Political Office for Somalia of 28.4.2010 116 provides another example of such a support.

The AMISOM's activities in Somalia have generally been assessed positively. Even though AMISOM is not an anti-piracy mission, nor is combatting piracy amongst its main objectives, its influence on the stabilization of the situation in Somalia has undoubtedly largely contributed to the decrease of piracy incidents. ${ }^{117}$ Furthermore, the UN Security Council underlined the importance of African Union operation for the establishment of lasting peace and stability in Somalia, simultaneously highlighting the need to protect the humanitarian assistance convoys of the mission. ${ }^{118}$

114 Mission's objectives evolved. See e.g. UNSC Resolution 1964 (2010) of 22.12.2010, para. 3 that related to the African Union Peace and Security Council recommendations of 15.10.2010 and also UNSC Resolution 2073 (2012) of 7.11.2012, para. 1, that refers to the AMISOM Strategic Concept of 5.1.2012. See also A. Lelarge, op. cit., at pp. 471-473.

115 UNSC Resolution 1863 (2009) of 19.1.2009.

116 Text available at: http://unpos.unmissions.org/Portals/UNPOS/Repository\%20 UNPOS/100428\%20MOU\%20AMISOM-IGAD-UNPOS.pdf.

117 According to the Report of the Chairperson of the Commission on the Situation in Somalia, submitted at the $163^{\text {rd }}$ meeting of the Peace and Security Council (22.12.2008), the Chairmen stated that "I would like to report that AMISOM, with its limited capability, provides active support to the fight against piracy. Indeed, the Mission has escorted ships carrying much-needed relief supplies from a distance of five nautical miles of the Mogadishu seaport" (point 29). Doc. PSC/MIN/4(CLXIII).

118 See for e.g. UNSC Resolution 1846 (2008) of 2.12.2008. 


\subsection{The Fight with Piracy from the Viewpoint of the African Union and Sub-regional Integration Organizations}

\subsubsection{African Union}

Although the activity of African integration organizations relating to the Horn of Africa is focused rather on eliminating the structural causes of piracy, this does not mean that they do not concern piracy at all. Their actions were primarily of political (the formulation of political statements) and legal character and, to a much lesser degree, operational. Taking the African Union as an example, these aims found their expression in particular in the documents of the Union's organs, in particular those of the Peace and Security Council, documents relating to conferences organized under the auspices of the Union and, to some extent, also in international agreements concluded between the Union's member states.

As the problem of Somali piracy intensified (2008), numerous communiqués of the Peace and Security Council on Somalia addressed that issue. The issue itself, however, is noted pars pro toto, as if on the margins of the main comments concerning the situation of Somalia and the role of AMISOM. Hence the Council, in its Communiqué of 18.1.2008 drew attention to "the persistence of the phenomenon of piracy off the coast of Somalia and its serious implications for security and delivery of humanitarian assistance to Somalia and calls all countries in a position to do so take appropriate steps to prevent and combat acts of piracy off the coast of Somalia, in line with the relevant provisions of UN Security Council resolution 1772(2007) of 20.8.2007" (para. 10). ${ }^{119}$ Nevertheless, the African Union does not take decisions in relation to pirates.

Another example is provided in the Peace and Security Council Communique of $15.10 .2010 .{ }^{120}$ The Council (para. 9) draws attention to the fact that the long-lasting solution to the Somali problem requires that "the underlying problems within Somalia itself and that other equally

119 See para 18 of the UNSC Resolution. The Security Council calls upon member states that have military ships and aircrafts "to be vigilant to any incident of piracy therein and to take appropriate action to protect merchant shipping, in particular the transportation of humanitarian aid, against any such act, in line with relevant international law".

120 Doc. PSC/MIN/1(CCXXXXV). 
serious scourges affecting the livelihoods and well-being of the Somali people, in particular, the dumping of toxic waste and illegal fishing off the coast of Somalia, be effectively and swiftly addressed". The Council also demanded that the African Commission undertake and continue to discharge efforts in order to ensure a:

[c]omprehensive approach to the issue of piracy, based on relevant AU decisions and conclusions of the workshop on maritime security and safety held in Addis Ababa on 4 and 5 April 2010, including the elaboration and conclusion of an international convention on the issue of piracy within the framework of the UN General Assembly.

The Commission was also obliged to establish a working group with the task of examining and contributing to the UN initiatives concerning the prosecution and punishment of piracy "with a view to making them more comprehensive". Finally, the Council requested that "the mobilization [...] displayed by the international community in the fight against piracy and armed robbery at sea, be also channelled in support of the ongoing efforts by the AU on the mainland". The Communiqué clearly shows that the regional organizations have the potential to not only implement, but also to initiate, UNSC resolutions, including on the matter of piracy (para. 15).

In the context of mainly political reaction of the African Union to piracy it is worth noting, inter alia, the Decision to combat the payment of ransom to terrorist groups, adopted by the African Union Assembly of Heads of States and Governments on 3.7.2009. ${ }^{121}$ This decision links the phenomenon of piracy and the taking of hostages and demanding ransom with the financing of terrorism. The Assembly condemned instances of paying ransom to terrorists and postulated that the international society

121 Assembly/AU/Dec.256(XIII). In the Communiqué from the $214^{\text {th }}$ meeting of the Peace and Security Council of 8.1.2010, the Council stated that "the persistence of the phenomenon of piracy off the coast of Somalia, which, through the payment of ransom money, contributes to criminality, terrorism and extremism in Somalia. In line with the relevant provisions of the Tripoli Declaration of 31.8.August 2009, Council discourse in its entirety the payment of ransom, pending the introduction of an appropriate legal instrument to criminalize the payment and receipt of ransom money (para. 10)". Doc. PSC/PR/Comm.(CCXIV). 
deem this as a crime. Moreover, it was proposed that the UN Security Council adopts a restrictive resolution in that respect in order to consolidate existing international and African regulations. The Assembly suggested that the General Assembly include in its agenda a topic concerning the negotiation of "supplementary protocol to the International Convention for the Suppression of the Financing of Terrorism or to the International Convention against the Taking of Hostages which prohibits the payment of ransom to terrorist groups".

The activity of the African Union is also to be observed on the basis of documents of the conference of ministers responsible for maritime transport. Among them, importantly, is the Durban Resolution on Maritime Safety, Maritime Security and Protection of the Marine Environment in Africa of 16.10.2009. ${ }^{122}$ The ministers condemned piracy and took note of the activity of sub-regional economic communities and the United Nations, as well as other international organizations on the continent. They obliged themselves to:

a. Support the efforts of the International Maritime Organization and United Nations' Security Council in coordinating an international response to the scourge of piracy along the coast of Somalia including the establishment of the piracy information Centers and building of subregional capacity and capabilities;

b. enact national legislation where appropriate and take all the necessary measures to give full effect to relevant international instruments in the area of maritime, port safety and security in order to ensure safe, secure, efficient, and environmentally friendly shipping;

c. Encourage the implementation of the Djibouti Code of Conduct concerning the Repression of Piracy and Armed Robbery against ships off the coast of Somalia and the Gulf of Aden, for those countries that are party to it.

Ministers recommended also to the African Union member states to adhere to various international agreements and resolutions concerning maritime safety and security and the protection of marine environment. They also decided to work jointly with a view to ratify and implement

122 AU/MT/MIN/DRAFT/Res. (II), available at: http://www.au.int/pages/sites/default/ files/Durban\%20resolution_1.pdf. 
those legal instruments. Moreover, the ministers agreed to establish or strengthen national maritime administrations or their counterparts, promote and support coordination and monitoring measures of regional and sub-regional character that aim to (a) enhance maritime safety and security, (b) facilitate international maritime traffic and protection of marine environment in Africa, (c) encourage regional economic communities to undertake additional projects in areas where the construction of local maritime capacity is needed, (d) support the initiative of the Maritime Organization for West and Central Africa and IMO concerning the establishment of the Integrated Coast Guard Function Network in the sub-region, (e) promote sub-regional cooperation and coordination pertaining to "the provision of coast guard functions inclusive of maritime intelligence, surveillance safety and security, protection of environment and search and rescue", (f) encourage regional communities to undertake or continue projects to the extent "local maritime capacity and sharing best business practices to enhance port security" is needed, (g) implement ISPS Code, and (h) encourage to strengthen "surveillance and patrolling capability, the sharing of information pertinent to maritime security and implement the Long Range Identification and Tracking System at Subregional and Regional levels".

The African Commission was called upon to adopt all measures necessary to implement the United Nations' instruments in the field of maritime safety and security and protection of marine environment. Member states were, in turn, called upon to secure necessary budgetary resources to implement recommendations and undertake further measures aimed at ensuring that effective communication net is in place in order to optimally use "the mechanisms for control, follow-up and intervention at sea and ensure better facilitation of international maritime traffic".

Maritime piracy constitutes one of the most serious obstacles to maritime trade. Nevertheless, within the framework of the Organization of African Unity it was possible to adopt an international agreement concerning maritime transport - African Maritime Transport Charter of $15^{\text {th }}$ December 1993 . This has been provisionally applied since that time. ${ }^{123}$

123 The Charter Has been applied provisionally Since it was signed by 20 OAU member states. Text available at: http://www.au.int/en/sites/default/files/Charter_En_African_ Maritime_Transport_Tunis_June1994.pdf. Though the Charter was signed by 39 states, it 
Characteristically, the Charter contains no explicit provision concerning piracy. This turn of events has meant, however, that on 26.7.2010, the Revised African Maritime Transport Charter ${ }^{124}$ was signed. The Revised Charter has so far been signed by only 12 states (the most directly affected states, including Somalia, are not among them) and ratified by three (Ethiopia, Benin and Togo). ${ }^{125}$ Symptomatically, it explicitly refers to piracy. It does so firstly in Article 12, which establishes a general obligation to cooperate in maritime and inland waterways. Article 12 para. 4 states that states parties agree to cooperate at regional, continental and international levels in particular with regard to "all unlawful acts, piracy, terrorism, etc." Further the Revised Charter, while regulating the issue of enhanced maritime safety and security (Charter VIII), lays the ground for an international instrument relating to maritime safety, maritime security and combating piracy (Article 26). Paragraph 2 of that provision stipulates that: "States Parties shall adopt effective measures to combat acts of piracy, armed robbery and other unlawful acts against shipping through co-operation with other international bodies".

\subsubsection{IGAD}

Apart from the African Union, IGAD and its member states (including Somalia, represented by the Transitional Federal Government) have played an important role in combating piracy. IGAD took actions both with regard to Somalia itself (IGASOM) and to Somali piracy as such, though the latter were similar in nature to those undertaken by the African Union. In that context, the political statement contained in the Communique issued following the $31^{\text {st }}$ extraordinary session of the IGAD Council of Ministers of 21.12.2008 ${ }^{126}$ is distinctive. It recalled that

Has been ratified till now by only 13 (as of 13.7.2012), whereas in order to enter into force, it needs to be ratified by $2 / 3$ of the African Union member states. Information available at: http://www.au.int/en/sites/default/files/Maritime\%20Transport\%20Charter_0.pdf.

124 Text available at: http://www.au.int/en/content/revised-african-maritimetransport-charter. The Charter repeals its predecessor and enters into force after ratification by 15 states (Article 49 para. 1).

125 Data as of 26.12.2012; available at: http://www.au.int/en/sites/default/files/ Revised\%20-\%20Maritime\%20Transport\%20Charter_0.pdf.

126 Text available at: http://www.operationspaix.net/DATA/DOCUMENT /3095 v Communique_of_the_31st_Extra-ordinary_Session_of_the_IGAD_Council_of_ Ministers_on_the_Security_and_Political_Situation_in_Somalia.pdf. 
it had been noted earlier that the escalation of piracy attacks along the territorial waters of Somalia:

[i]s a symptom of the overall economic, political, security and social problem afflicting Somalia in the last 18 years, and that sustainable solution can only be achieved through addressing the root causes, in particular through the establishment of institutions of governance and protection of the people of Somalia (para. 14).

The position of the IGAD Council of ministers is later confirmed by the IGAD Summit organized together with the African Union Summit on 30.1.2009. It was noted that a number of UNSC resolutions authorized the use of force against pirates and call upon states and international organizations to act. It was officially recognized that there is a role to play in that respect by African organizations. A study concerning the impact of piracy on the IGAD region was presented in 2009.

It is interesting to note the Communique on Somalia issued at the ordinary session of the IGAD Council of Ministers on 8.12.2009. ${ }^{127}$ The Council of Ministers stated therein that, notwithstanding the presence of large military forces in and around the Gulf of Aden, the threat of maritime piracy increased. Interestingly, it highlighted that not only is piracy a symptom of a bigger problem of destabilized situation in Somalia but also a source of crime in and around Somalia, as well as a contributing factor to the strengthening of terrorist and extremist movements. Hence, as the Council of Ministers sees it, piracy is not only a consequence of Somalia as a failed state but it also brings about chaos in that country. IGAD Council of Ministers called for the combating of piracy in a holistic way, in cooperation with Transitional Federal Government of Somalia, IGAD member states, African Union and international community as a whole (paras 17 and 18).

On 21.7.2010 IGAD Secretariat developed and presented Terms of reference - Drafting of a Somalia Inland Action Plan to Counter and Prevent Piracy 2010-2015. This was the result of a collaboration between Eastern and Southern Africa and the Indian Ocean Commission (IOC),

127 Text available at: http://igad.int/attachments/155_Council_Communique_on_ Somalia.pdf. 
where the IGAD was responsible for developing an action plan with regard to territorial Somalia. It was based on the assumption that countering piracy is impossible without re-establishing the rule of law in Somalia. The IGAD Secretariat designated three basis objectives of Action Plan:

1. Ways to initiate home grown solutions to prevent and repress piracy, by addressing the root causes of this phenomenon.

2. Support Somali authorities in addressing impunity (investigation and prosecution) related to trans-national crimes related to piracy (money laundering, traffic of weapons etc).

3. Reinforce Somali authorities (Coast Guards, Customs etc) in the delimitation of Somali EEZ and its control and surveillance, to impede acts of piracy and other trans-national crimes (e.g. illegal fishing, dumping of toxic wastes etc.).

\subsubsection{Common Market for Eastern and Southern Africa (COMESA)}

COMESA unequivocally considers piracy as a threat to international peace and security and recognizes the primary role of the United Nations in countering that phenomenon. Piracy is viewed as equivalent to armed robbery. It is also linked with the need to eliminate the root causes of piracy inherent in the Somali situation. For example, the Final Communique of the Summit meeting of the Heads of State and Government, issued on 8.6.2009 in Victoria Falls Town (Zimbabwe), underlined that "the rising incidence of piracy off the Coast of Somalia and the Mozambican Channel that has a significant negative impact on the economies of COMESA Member States and constitutes a threat to peace and security in the region". In that context, acts of piracy were strongly condemned. Heads of states and governments jointly called upon the international community to act in a holistic manner, designating the United Nations as the appropriate forum to take decisions and react ${ }^{128}$.

It is worth noting the final part of the Declaration of the COMESA Ministers Responsible for Transport, and Communications, Information Technology and Energy of 28.10.2009 (Djibouti), entitled "Sea Piracy in

128 Text available at: http://www.zimfa.gov.zw/index.php?option=com_content\& view=article\&id=117:13-th-comesa-summit-final-communique. 
the Gulf of Aden and the Indian Ocean". The Ministers recognized that piracy (including armed robbery) constitutes a "serious and immediate threat" which needs to be strongly condemned. Piracy and armed robbery are clearly seen as "a serious threat to peace and security at the regional and international levels and to development efforts made by COMESA Member States". Accordingly, member states are called upon to sign and ratify the Djibouti Code of Conduct that is characterized as "an indispensable instrument for the eradication of sea piracy form the Gulf of Aden and off the coast of Somalia". Moreover, the ministers present in Djibouti requested that the international community "supports and contributes to reaching the objectives set in Djibouti Code of Conduct, including the establishment of the regional training centre" 129 .

The Final Communique of the $14^{\text {th }}$ Summit of the Authority of the COMESA of 1.9.2010 expresses serious concern regarding the increase in the number of piracy and armed robbery incidents and condemned "all crimes associated with piracy, including money laundering and human trafficking". It was also recommended that the COMESA member states develop "a comprehensive regional action plan and strategy to address the problem of piracy facing the region"130. Lastly, the Final Communique of $16^{\text {th }}$ Summit of the COMESA Authority of Heads of State and Government of 24.11.2012 calls upon international community to "to urgently release resources to address the problem through the implementation of the Eastern and Southern Africa Indian Ocean (ESA-IOC) Maritime Security Plan of Action developed by COMESA and its partners" and to cooperate with COMESA, African Union, its regional partners from East Africa and Indian Ocean region and its member states in order to intensify efforts aimed at implementing the Action Plan and Strategy. It was also recommended that the COMESA implements, fully and speedily, the Action Plan and Strategy on Anti Money Laundering Programme with a view to ensuring that profits stemming from piracy were not used or invested in the region ${ }^{131}$.

129 Text available at: http://www.whoownswhom.co.za/public/africainc/trade_ agreements/COMESA\%20-\%20MINISTERIAL\%20DECLARATION\%20_DJIBOUTI.pdf.

130 Text available at: http://www.tma.org/tmalive/Html/Advertisements/Comesa\%20 Summit\%20Communique\%20September\%202010.pdf.

131 http://www.tralac.org/files/2012/12/COMESA-Final-Communique-241120120912hrs.pdf. 


\subsubsection{East African Community (EAC)}

The East African Community has also acted against piracy between Africa and Asia. For example, at the $7^{\text {th }}$ Meeting of EAC Sectoral Council on Transport, Communications and Meteorology (12.2.2010), the ministers stated that the still present threat of piracy has "serious economic and transportation impacts for the region". Accordingly, they called upon partner states to further support the IMO, the African Union, IGAD and other international organizations engaged in combating piracy, including implementation of the Djibouti Code of Conduct. Moreover, they recommended that the EAC Secretariat "develop an agreement on cooperation in preventing and suppressing acts of piracy and armed robbery against ships in line with recommendations of the International Maritime Organization (IMO)" and "develop a proposal on the establishment of a regional maritime patrol unit in order to pool resources together and to tap into the international goodwill currently available for funding such a unit".

The Joint Communiqué of $12^{\text {th }}$ Ordinary Summit of the EAC Heads of State of 3.12.2010 noted in turn that "although there was a heavy presence of foreign navies in the Indian Ocean and the Gulf of Aden, piracy incidents have increased and have extended further south into the territorial waters of the EAC Partner States. The Summit noted that piracy was increasingly becoming a serious economic and security threats to the region. The Summit called for coordinated efforts at national, regional and international levels to address the threat". ${ }^{132}$

\section{Cooperation between African Regional Integration Organizations}

Regional integration organizations have reacted to piracy threat both individually and collectively. As regards the latter, it is appropriate to draw attention to meetings of ministers for the Eastern and Southern Africa and Indian Ocean region and EU High Representative that related

132 Text available at: http://www.eac.int/news/index.php?option=com_docman\&Itemi $\mathrm{d}=77$ \&limitstart $=10$. 
to piracy and maritime safety and security in the Eastern and Southern Africa and Indian Ocean region. Notwithstanding the fact that most state representatives were present, representatives of such organizations as COMESA, EAC, IGAD, SADC and African Union also participated. In one of the joint communiqués that concluded the meeting of ministers of the region at Grand Bay (Mauritius) on 7.10.2010 ${ }^{133}$, it was noted with appreciation that, inter alia, the political organs of COMESA, EAC and IGAD adopted political decisions concerning combating piracy and obliged themselves to bilateral, regional and international cooperation regarding the comprehensive fight with pirates and promoting maritime safety and security. Ministers also acknowledged the Action Plan for the fight against Piracy adopted at the COMESA summit and the fact that a specific Plan of Action for Inland Somalia was being developed. They also recognized the key role of EU ATALANTA mission and the cooperation of states in the region in combating piracy. The meeting also considered and adopted a regional strategy establishing the framework for the prevention and combating of piracy and for promoting maritime safety and security. It consisted of three main pillars: (1) developing and implementing the Somalia Inland Action Plan to Counter and Prevent Piracy; (2) encouraging states of the region to prosecute and punish pirates captured in the region, with the involvement of financial and technical support granted by the international community; (3) strengthening the capacity of states of the region to ensure the safety of their maritime zones.

The ministers adopted a Regional Plan of Action based upon crosscutting principles involving the exchange of information, cooperation, joint action and capacity-building. They also decided that regional meetings, involving members states and regional economic communities, will serve as a Regional Coordination Mechanism responsible for the timely and effective implementation and follow-up of the Regional Strategy and Regional Plan of Action. Moreover, the Inter-Regional Coordination Committee (IRCC) has begun to serve as a Mechanism's Secretariat in charge of preparing the annual ESA-IO Regional Ministerial Meeting against Piracy. Regional Strategy and Regional Plan of Action were recognized as complementary to the African Maritime Transport Charter

133 Text available at: http://www.consilium.europa.eu/uedocs/cms_Data/docs/ pressdata/EN/foraff/116942.pdf. 
and as constituting an additional basis for strengthening cooperation in the fields of political dialogue and cooperation concerning the combatting of piracy and ensuring maritime safety and security, with such partners as the United Nations and the European Union. The ministers called upon international partners, in particular the EU, to deliver assistance and to ensure that the follow-up to the Communique took place through the Network of Contact Point on Piracy.

\section{Concluding Remarks}

An analysis of the piracy problem between Africa and Asia shows that the traditional approach of international law to preventing and countering that crime may not be successful. The reason for this lies not in the fact that Somali piracy differs from piracy elsewhere in the world but, rather, in the fact that the development of Somali piracy is inextricably linked with the situation in that failed state, without a government capable of displaying effective authority over the whole territory. In consequence, pirates could find support on land, among the local population. They could also conduct their activities from land, in the internal waters and territorial sea, and utilize favourable geographical and climate conditions to that end.

The international community has reacted to the Somali piracy, adding to the traditional notion of piracy that of armed robbery and extending the legitimate external response to piracy to apply to Somalia's territorial sea. However, it must be stressed that this was done, formally, while respecting Somalia's sovereignty and territorial integrity and only after having obtained the prior consent of the Transitional Federal Government. The international community, acting in particular through the UN Security Council, has warranted that the Somali case cannot be considered as a law-making phenomenon which leads to the creation of customary international law. One may wonder, however, whether the reaction of the international community in similar circumstances would, or even should, be any different. One can also ponder, though this issue is more controversial given the characteristics of states and their capacity to conduct military actions, how the reaction of the international community should look in the event that piracy is supported by a rogue 
state (providing security to pirates). In any event, the reservation concerning international customary law should, one can assume, mean that international community does not intend, on the basis of the Somali case, to create a rule of a general character. In other words, it desires that even a prima facie similar situation should be analysed individually. Accordingly, the international community is against individual states taking action, using the Somali case as the precedent for such action, in the territorial sea or land territory of any state without that state's consent, whilst claiming that it does so because the state in question is a failed one.

The reaction of the international community to piracy between Africa and Asia is multi-dimensional. It is possible to discern a growing conviction that it is necessary to link combatting piracy with the elimination of its 'territorial' causes and that the approach need to be both holistic and integrated. This approach includes not only a broad spectrum of measures, which were eventually adopted, but also multiple entities, including regional organizations, whose actions require coordination at different levels.

Regional integration organizations, in particular the European Union and African integration organizations, became active participants in actions seeking to prevent and combat piracy and armed robbery. The international community views their role, firstly, with regard to stabilization of the situation in Somalia, and sometimes also with regard to countering piracy. Varying causes led to the involvement of the European Union and African organizations in the region. The European Union pursued primarily economic aims, namely to ensure safe transport and fishing. African organizations and their members were inspired in particular by the need to ensure their own security and to stabilize the region, although economic reasons were not without importance.

The UN Security Council, while authorizing regional integration organizations to take actions with regard to piracy or Somalia, noted that this is an important link in maintaining peace and security in the region, conducive to coordinating regional efforts. It also stressed the fact that piracy was explicitly regarded as a threat to international peace and security. In that context, the actions of the regional integration organizations considered above have an implementing nature. Upon closer inspection, however, these organizations initiated measures that were 
subsequently approved by the Security Council. At the same time it must be highlighted that, as regards preventing and combatting piracy, regional integration organizations cannot act as a substitute for, on the one hand, the UN Security Council (with regard to granting authorization to act, especially the use of armed force) or even the IMO (given its standardsetting role) and, on the other hand, states, including member states, who are the only actors which factually have at their disposal military, security and civil forces.

Nevertheless, it is difficult to undermine the role of regional integration organizations. They proved to be a useful tool for states to act but also important conceptual, operational, political and coordination centres. From the political viewpoint and the need secure a coordinated response to piracy, integration organizations have undoubtedly allowed for greater collective action and cooperation of member states, without removing their flexibility to act (integration organizations have often authorized states to participate in missions without imposing any duties) and they have also facilitated much needed cooperation between general (the UN, IMO), regional and inter-regional level, as well as between governmental and non-governmental institutions.

From the legal perspective, regional integration organizations have contributed to ensuring the respect for international law, including recommended standards, and to regional and national implementation, compliance and enforcement. The integration organizations themselves are also subject to international law, in particular to UNSC resolutions and treaties concerning the law of the sea, international criminal law and human rights treaties. It seems possible that they would be held internationally responsible for any breaches of international law in respect of states, including Somalia, and individuals, including pirates, as regards breaches of applicable human rights norms. At the same time, it seems highly improbable (also due to the fact that clauses for the respect of international law were included in authorizing legal instruments) that potential breaches would occur as consequences of concrete actions and these were rather reserved for states.

Finally, in the operational sense, the regional integration organizations provided an effective link between political, diplomatic, the rule of law, training, security, judicial and military (land, airborne and maritime) actions. Thus, they enabled agreements to be reached faster and order 
to be introduced in Somalia, as well as better protection of ships with humanitarian assistance, trade, fishing and passenger vessels, more effective anti-piracy efforts and ensuring that pirates will not be able to act with impunity.

Simultaneously, the role of the European Union and African integration organizations, strictly from the perspective of preventing and punishing Somali piracy, has proved to be very different, albeit complementary. Whilst the former, through some of its members states and also third, partnering states, was capable of undertaking factual operational measures directed against pirates and to capture and punish at least some of them, the latter (albeit with substantial external support) proved to be important structures ensuring lasting stabilization and the rule of law on land, thus contributing to the elimination of the true causes of piracy between Africa and Asia. 